\title{
Lessons from the Smartphone Wars: Patent Litigants, Patent Quality, and Software
}

\author{
Ronald A. Cass*
}

\begin{abstract}
Commentators, public officials, and scholars have sounded alarms over the smartphone patent wars-hundreds of cases asserting infringement of patents by makers of smartphones and tablet computers-often suggesting broad, categorical "fixes" to problems this litigation reveals. In general, these recommendations sweep too broadly, throwing out good claims as well as bad and needed remedies as well as questionable ones. However, calls for attention along two margins promise improvements. One factor, the identity of the enterprise asserting patent rights, already is being used by courts in considering appropriate patent infringement remedies, but its use needs to be refined. The other factor, patent qualityespecially in software patents, where the existence of parallel schemes of intellectual property protection exacerbates quality problems-is even more critical to the way the system operates. Addressing the patent quality issue (which is distinct from patent clarity or patent notice) can do more than other reforms to reduce costs without reducing innovation incentives.
\end{abstract}

\section{(C) 2015 Ronald A. Cass}

* Dean Emeritus, Boston University School of Law; Senior Fellow, International Centre for Economic Research; President, Cass \& Associates, PC. Dean Cass also is former Commissioner and Vice-Chairman of the U.S. International Trade Commission, a U.S. Representative Member, International Centre for Settlement of Investment Disputes (Panel of Conciliators), and a Council Member, Administrative Conference of the United States. Support was provided by the Center for the Rule of Law and the International Centre for Economic Research. 
I. Promoting and Protecting Innovation .............................

II. Smartphone Patent Fights...............................................11

A. Mobile Devices: Evolving Products, Markets,

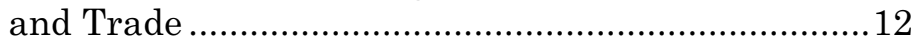

B. Smartphone Patent Wars: What and Why .................15

III. Trolling for Answers in the Thicket................................24

A. New or Used: Solutions to the Smartphone Patent Problem .......................................................24

B. That's the Thicket: Transaction Costs and Hold-

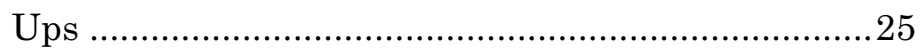

C. Patent Pools and Cross-Licenses..............................27

D. Non-Practicing Entities (NPEs) .................................32

E. Patent Assertion Entities (PAEs)................................37

IV. Software: Patently Problematic? .......................................45

A. Software in Patent and Copyright Law: First

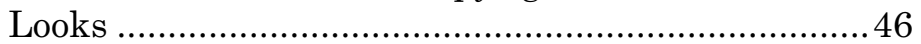

B. Fitting Software in the Intellectual Property

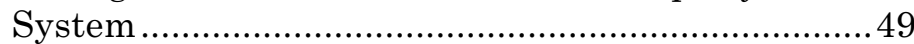

C. Software and Patent: Unpacking the Problems .......52

D. Overbreadth and Patent Quality ..............................52

E. Necessity for Patent Protection..................................56

F. Overlap and Overprotection ....................................57

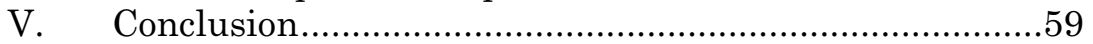

\section{INTRODUCTION}

In August 2012, a jury in San Diego, California, returned a verdict for damages in the amount of over $\$ 1$ billion in favor of Apple Inc. after finding that Samsung had infringed several patents protecting design and operating features of Apple's iPhones and iPads. ${ }^{1}$ The verdict, arrived at in only twenty-one hours, despite having to address 700 questions and review trial testimony that stretched over four weeks, valued the infringed patents at approximately forty-eight dollars per device. ${ }^{2}$ That

1. See, e.g., Josh Lowensohn, Jury Awards Apple More than $\$ 1$ Billion, Finds Samsung Infringed, CNET (Aug. 24, 2012, 3:53 PM), http://www.cnet.com/news/jury-awards-apple-more-than-1b-finds-samsung-in fringed/.

2. See, e.g., Billy Gallagher, Apple Awarded $\$ 1.049$ Billion in Damages as Jury Finds Samsung Infringed on Design and Software Patents, 
value shocked some observers, as the patent claims at issue covered minor aspects of design and operation. ${ }^{3}$ Given the magnitude of both patented components and methods of operation potentially at issue in every smartphone or similar mobile communication device-commonly estimated at 200,000 to $250,000^{4}$ - that valuation would plausibly suggest that even without any investment in parts, assembly, marketing, or other commercial costs, these items should each retail somewhere in the $\$ 2$ million range, which is between 3,000 and 40,000 times the actual prices of these devices. ${ }^{5}$

With stories like this (and the McDonald's coffee case) in mind, the rest of the world looks at the American trial system with views that range between amusement and apoplexy. ${ }^{6}$

TECHCRUNCH (Aug. 24, 2012), http://techcrunch.com/2012/08/24/apple-wins-pa tent-ruling-as-jury-finds-samsung-infringes/; Brian J. Love, Apple-Samsung Patent Fight: Fuzzy Math, L.A. Times (Aug. 30, 2012), http://articles.latimes.com/2012/aug/30/opinion/la-oe-love-apple-patent-damag es-20120830; Nick Wingfield, Jury Awards \$1 Billion to Apple in Samsung Patent Case, N.Y. Times (Aug. 24, 2012), http://www.nytimes.com/2012/08/25 /technology/jury-reaches-decision-in-apple-samsung-patent-trial.html?_r=2\&.

3. See, e.g., Haydn Shaughnessy, Why the Apple vs Samsung Verdict Is a Big Mistake, Forbes (Aug. 26, 2012, 7:27 AM), http://www.forbes.com/sites/haydnshaughnessy/2012/08/26/why-the-apple-vs -samsung-verdict-is-a-big-mistake/.

4. See, e.g., L. Gordon Crovitz, Google, Motorola and the Patent Wars, WALL ST. J., Aug. 22, 2011, at A11, available at http://online.wsj.com/article /SB10001424053111903639404576518493092643006.html; Steve Lohr, AppleSamsung Case Shows Smartphone as Legal Magnet, N.Y. TIMES (Aug. 25, 2012), http://www.nytimes.com/2012/08/26/technology/apple-samsung-case-sh ows-smartphone-as-lawsuit-magnet.html; Mike Masnick, There Are 250,000 Active Patents That Impact Smartphones; Representing One in Six Active Patents Today, TECHDIRT (Oct. 18, 2012, 8:28 AM), https://www.techdirt.com/blog/innovation/articles/20121017/10480520734/ther e-are-250000-active-patents-that-impact-smartphones-representing-one-six-ac tive-patents-today.shtml.

5. See supra notes 2,4 .

6. See, e.g., Liebeck v. McDonald's Rests., P.T.S., Inc., No. CV-93-02419, 1995 WL 360309 (D.N.M. Aug. 18, 1994); Aric Press et al., Are Lawyers Burning America?, NewsweEK, Mar. 20, 1995, at 32; Alex Kozinski, The Case of Punitive Damages v. Democracy, WALL ST. J., Jan. 19, 1995, at A18 (discussing a seventy-nine-year-old woman, Stella Liebeck, who famously opened a cup of McDonald's coffee that she had propped between her legs, spilling the coffee and suffering third-degree burns; she sued, claiming that McDonald's served its coffee twenty to thirty degrees hotter than the norm for restaurant coffee, and received a jury verdict for $\$ 2.9$ million, including $\$ 2.7$ million in punitive damages, which was widely ridiculed and satirized as a $\$ 3$ million dollar payment for McDonald's failure to warn customers that hot coffee can be hot). 
Anything as complex and difficult to evaluate as the role that specific features play in product design and composition or the degree to which certain features mimic others is surely beyond the ken of the men and women who comprise American juries. ${ }^{7}$ There certainly is much to be concerned about in turning these decisions over to lay juries, yet given the American Constitution's express protection for historic rights to jury trial, this peculiar feature of our legal system is not likely to change. ${ }^{8}$ Juries do not have the last word - the district court judge in Apple Inc. v. Samsung Electronics Co., Ltd. denied Apple's petition to increase damages against Samsung and granted Samsung's petition to reduce damages, which first were cut in half by the judge, then vacated for a new calculation of what should be owed 9 - but they do play an important role. ${ }^{10}$

Despite legitimate concerns over the role of juries, this peculiar American process is not the only feature driving results like those in the Apple-Samsung case. Equally important is the design of the American intellectual property system, which has come under fire for producing results like the Apple-Samsung verdict. ${ }^{11}$ After all, the jury verdict was possible only because certain aspects of the American patent law system (both the substantive law and the procedures for implementing it) provided avenues for placing particular questions before the jury and for potentially answering the questions as the jury did. ${ }^{12}$ Notably, the law gave scope to find

7. See generally Andrea Gerlin, A Matter of Degree: How a Jury Decided That One Coffee Spill Is Worth \$2.9 Million, WALL ST. J. EuR., Sept. 2, 1994, at 1,6 (discussing how jurors handled the McDonald's coffee case, which involved a product significantly less complex than smartphones).

8. See U.S. Const. amend. VII.

9. See, e.g., Brian X. Chen, Jury to Decide How Much More Samsung Must Pay Apple in Patent Case, N.Y. TIMES, Nov. 12, 2013, at B3; Ian Sherr, U.S. Judge Reduces Apple's Patent Award in Samsung Case, WALL ST. J. (Mar. 1, 2013, 5:57 PM), http://online.wsj.com/article/SB1000142412788732347830 4578334540541100744.html.

10. See, e.g., Kozinski, supra note 6.

11. See, e.g., James Bessen \& Michael J. Meurer, Patent Failure: How Judges, Bureaucrats AND LAWyers Put InNovators AT Risk 1-28 (Princeton Univ. Press ed., 2008) (introducing their general criticism of the current patent system); Steven Levy, The Patent Problem, WIRED (Nov. 13, 2012, 6:30 AM), http://www.wired.com/opinion/2012/11/ff-steven-levy-the-pat ent-problem/all/.

12. See, e.g., Reza Mirzaie, Weighing the Role of Juries in Patent Cases, 36 L.A. LAW. 13 (2013), available at http://www.lacba.org/Files/LAL/Vol36No5 /3060.pdf. 
that the patents covering relatively modest advances in technology and relatively obvious design features were validly granted the powerful protection of patent rights and also provided vehicles for drawing conclusions about the value of those patents-and the best ways to protect the associated patent rights-that led to the much-discussed result. ${ }^{13}$

More troubling than the outcome in a single case, the Apple-Samsung trial is only one outcropping in the landscape of legal proceedings over patents used today in the production and operation of smartphones and tablet computers. Hundreds of cases involving the major producers of these mobile communications and computing devices have been filed in the courts and with the U.S. International Trade Commission (ITC), a century-old administrative agency that shares jurisdiction over trade-related patent contests with U.S. district courts. ${ }^{14}$ In the last few years, Samsung and Apple alone have filed scores of claims against one another in several jurisdictions in the United States, before the ITC, and in courts in at least ten countries. ${ }^{15}$ Add to that the cases involving HTC, Kodak, Microsoft, Motorola, Nokia, and Research in Motion (RIM), maker of the BlackBerry, and you have a substantial proportion of recent patent cases. ${ }^{16}$

13. See, e.g., infra notes 102-06 and accompanying text. U.S. Supreme Court decisions over the last few years have pushed the law in a different direction. See generally Alice Corp. Pty. Ltd. v. CLS Bank Int'l., 134. S. Ct. 2347, 2347 (2014) ("We hold that the claims at issue are drawn to the abstract idea of intermediated settlement, and that merely requiring generic computer implementation fails to transform that abstract idea into a patent-eligible invention."); Bilski v. Kappos, 561 U.S. 593 (2010).

14. See, e.g., U.S. InT'L Trade COMM'N, FACTS AND TRENDS REgarding USITC SECTION 337 INVESTIGATIONS (2013), available at http://www.usitc.gov /press_room/documents/featured_news/sec337factsupdate.pdf.

15. See, e.g., Mariko Yasu \& Naoko Fujimura, Apple Loses Patent Lawsuit Against Samsung in Japan, BLOOMBERG (Aug. 31, 2012, 12:16 PM), http://www.bloomberg.com/news/2012-08-31/apple-loses-japan-patent-lawsuit -against-samsung-over-devices.html; see also Lohr, supra note 4.

16. See, e.g., Colleen V. Chien \& Mark A. Lemley, Patent Holdup, the ITC, and the Public Interest, 98 CORNELL L. REV. 1, 3 (2012); Crovitz, supra note 4; Ming-Jeong Lee \& Jonathan Cheng, Samsung Patent-Licensing Deal Is Reached with Google, WALL ST. J., Jan. 27, 2014, at B6, available at http://www.wsj.com/news/articles/SB1000142405270230327770457934579138 8237228; Lohr, supra note 4 (stating that although some of the major litigants have begun negotiating settlements, a significant body of litigation remains); Brid-Aine Parnell, Nokia and HTC Throw Down Swords, Sign Patent War Peace Treaty, REGISTER (Feb. 11, 2014), http://www.theregister.co.uk/2014 /02/11/nokia_htc_patent_agreement. 
Commentators looking at these cases have offered disparate views on whether these cases suggest problems with the patent system and, if so, what needs to be done.17 Recommendations have included making it more difficult to secure injunctions against patent infringement, limiting relief available to entities that do not practice the patents at issue in litigation, raising the threshold for patent awards, and eliminating patent protection for software. ${ }^{18}$

This Article examines what the smartphone wars tell us about stresses within American patent law (and more broadly American intellectual property (IP) law) and explores possible changes that might help improve the law. By and large, the patent system works, and most suggestions for major change are not supported by strong data and analysis, but calls for attention along two margins promise needed improvements. ${ }^{19}$ One factor, the identity of the enterprise asserting patent rights, already is being used by courts when considering appropriate patent infringement remedies. ${ }^{20}$ The other factor, patent quality (especially in software patents), is even more critical to the way the system operates. ${ }^{21}$ The patent quality issue is not the same as the question of patent clarity or patent notice stressed by other scholars. ${ }^{22}$ Addressing problems of

17. See, e.g., Chien \& Lemley, supra note 16, at 39-43 (discussing how $e$ Bay resulted in patentees going to the ITC to obtain "an injunction no longer available in the federal district courts"); Levy, supra note 11.

18. See Jason Albert, Microsoft CorP., COMments of Microsoft CORPORATION ON THE IMPACT OF PATENT ASSERTION ENTITY ACTIVITIES ON INNOVATION AND COMPETITION (2012), available at http://www.justice.gov/atr /public/workshops/pae/comments/paew-0042.pdf; Tim Wu, Weapons of Business Destruction: How a Tiny Little "Patent Troll" Got BlackBerry in a Headlock, SLATE (Feb. 6, 2006, 3:04 PM), http://www.slate.com/articles/news _and_politics/jurisprudence/2006/02/weapons_of_business_destruction.single.h tml.

19. E.g., William G. Barber, The U.S. Patent System Works, N.Y. TIMES (Oct. 10, 2012, 5:43 PM), http://www.nytimes.com/roomfordebate/2012/10/10 \%20does-the-law-support-inventors-or-investors/the-us-patent-system-works.

20. See generally James W. Soong, Patent Damage Strategies and the Enterprise License: Constructive Notice, Actual Notice, No Notice, 4 DUKE L. \& TECH. REV., no. $1, \quad 2005$, at 1-2, available at http://scholarship.law.duke.edu/cgi/viewcontent.cgi?article=1122\&context=dltr (expressing how patentees of enterprise software patents can still assert alternative notice theories when these patentees want to preserve legal remedies).

21. See infra Parts III, IV.

22. Compare, e.g., the discussion of patent quality issues, infra Parts II, IV, with BESSEN \& MEURER, supra note 11, at 120-32; see also John R. Allison 
weak patents can do more than other reforms to reduce costs without reducing innovation incentives. ${ }^{23}$

\section{PROMOTING AND PROTECTING INNOVATION}

At the outset, it is important to keep in mind the case in favor of patents. So much has been written in the past halfcentury questioning the case for a patent system (or at least one that looks like current patent law) that it is worth recalling the underlying sense of patent law. ${ }^{24}$ Fritz Machlup recounted four distinct, but overlapping, explanations supporting why patents should grant exclusive rights to inventors:

The "natural-law" thesis assumes that man has a natural property right in his own ideas ... . Property is, in essence, exclusive. Hence, enforcement of exclusivity in the use of a patented invention is the only appropriate way for society to recognize this property right.

The "reward-by-monopoly" thesis assumes that justice requires that a man receive reward for his services in proportion to their usefulness to society... [with inventive activity best secured by temporary] exclusive patent rights in their inventions.

The "monopoly-profit-incentive" thesis assumes that ... inventions and/or their exploitation will not be obtained in sufficient measure if inventors and capitalists can hope only for [competitive levels of profit from inventive activity] ... . The simplest, cheapest, and most effective way for society to hold out [incentives for enough profit to induce the appropriate amount of inventive activity] is to grant temporary monopolies in the form of exclusive patent rights in inventions.

The "exchange-of-secrets" thesis presumes a bargain between inventor and society, the former surrendering the possession of secret knowledge in exchange for the protection of a temporary exclusivity in its industrial use. ${ }^{25}$

\& Ronald J. Mann, The Disputed Quality of Software Patents, 85 WASH. U. L. REV. 297, 334 (2007).

23. E.g., Carl Shapiro, Patent Reform: Aligning Reward and Contribution, in InNOVATION POLICY AND THE ECONOMY 111, 111-15 (Adam B. Jaffe et al. eds., 8th ed. 2008).

24. See, e.g., BESSEN \& MEURER, supra note 11, at 120-32; Michele BOLDRIN \& DAVID K. LEVINE, AGAINST INTELLECTUAL MONOPOLY 15-67, 14983 (Cambridge Univ. Press ed., 2008). While debate over the justification for and proper scope of a patent system has gone on for more than two centuries, the intellectual assault on patents accelerated again in the past fifty years after a period of relative quiet. See, e.g., Peter J. Toren, The Assault on Patents, HiLl (Aug. 13, 2014, 10:00 AM), http://thehill.com/blogs/congress-blog /judicial/214943-the-assault-on-patents.

25. Fritz Machlup, COMM. ON THE JUdiciary, Subcomm. ON PATENTS, TRADEMARKS \& COPYRIGHTS, 85TH CONG., STUdY ON AN ECONOMIC REVIEW OF THE PATENT SYSTEM 21 (1958). Machlup distinguished the second thesis, 
Although the natural law argument doubtless was a source of early support for patents and continues to play a role in shaping intellectual property rights in Europe, ${ }^{26}$ the primary support for patent has centered on the consequentialist arguments, essentially the costs and benefits of using exclusive rights as a spur to increased innovation. ${ }^{27}$ The U.S. Constitution, for example, ties intellectual property rights directly to consequential social benefit in declaring that the national government will have the power "To promote the Progress of Science and useful Arts, by securing for limited Times to Authors and Inventors the exclusive Right to their respective Writings and Discoveries." 28

Likewise, the effectiveness of intellectual property law, including patent law, at securing public benefits, rather than securing private benefits while generating public costs, has been a main focus of debate in the law. ${ }^{29}$ The debate largely has been framed in static cost terms, comparing the value of

as provision of a just reward for invention, from the third, as provision of a sufficient reward, to call forth the optimal (or more nearly optimal) amount of invention. See id.

26. See, e.g., Wendy J. Gordon, A Property Right in Self-Expression: Equality and Individualism in the Natural Law of Intellectual Property, 102 YALE L.J. 1533, 1540-44 (1993) (discussing the progression of the natural law approach to intellectual property); see also Adam Mossoff, Rethinking the Development of Patents: An Intellectual History, 1550-1800, 52 HASTINGS L.J. 1255, 1256-59 (2001) (challenging the "prevailing view that the ideas of ... natural rights... did not influence the early development of patent law").

27. See, e.g., Edmund W. Kitch, The Nature and Function of the Patent System, 20 J.L. \& ECON. 265, 266 (1977); Robert P. Merges \& Richard R. Nelson, On the Complex Economics of Patent Scope, 90 CoLUM. L. REV. 839, 868-78 (1990). Machlup distinguished "invention" from "innovation," which he defined as a novel function that could, but need not, embody the practical application of an invention. See MACHLUP, supra note 25, at 56, 78. I do not similarly differentiate between the two terms, given the requirement that patentable inventions be novel and practical and the fact that virtually all contests respecting patents involve those that are put into practical use.

28. See U.S. Const. art. I, § 8, cl. 8.

29. See, e.g., BESSEN \& MEURER, supra note 11, at 120-32; BOLDRIN \& LEVINE, supra note 24, at 15-67, 149-83; LAWRENCE LESSIG, FREE CULTURE: How Big Media Uses Technology and the Law to Lock Down Culture AND Control Creativity (Penguin Press 2004); Stephen Breyer, The Uneasy Case for Copyright: A Study in Copyright of Books, Photocopies, and Computer Programs, 84 HARV. L. REV. 281, 326-30 (1970); F. Scott Kieff, Coordination, Property, and Intellectual Property: An Unconventional Approach to Anticompetitive Effects and Downstream Access, 56 EMORY L.J. 327, 397 (2006) (offering a more positive assessment of the cost-benefit calculation). 
increased innovation induced by the award of property rights in patented innovations to the cost of decreased use due to monopoly pricing of patented innovations. ${ }^{30}$ Although, increasingly, scholars have recognized more important, dynamic aspects of patent law, ${ }^{31}$ the tools of standard microeconomic analysis - and the allure of analysis built on anecdote-continue to tilt discourse on the patent system toward evaluation in terms of static effects. ${ }^{32}$

Machlup ultimately was agnostic about the economic analysis of patent rights' costs and benefits, but ended his review with a version of Pascal's wager, saying that in the absence of conclusive evidence it would be irresponsible to eliminate a system that has been in place for nations that have made great strides in innovation. ${ }^{33}$ Certainly, there is much that is unknown, and probably unknowable, about the degree to which patent law promotes investment in innovation (as opposed to merely shifting investment among different potential sources of innovation), about the benefits of patent law (both the stock of current law and its role in improving the flow of innovative ideas) in comparison to costs in restricting patent use, and about the precise calibration of various aspects of patent law. ${ }^{34}$

30. E.g., ARnold Plant, The Economic Theory Concerning Patents FOR INVENTIONS (1934), reprinted in ARNOLD PlANT, SELECTED ECONOMIC ESSAYS AND ADDRESSES 35 (Routledge \& Keegan Paul eds., 1974).

31. See, e.g., Ronald A. CASs \& Keith N. Hylton, LaWs of Creation: Property Rights IN THE WORLD OF IDEAS 49-75 (Harvard Univ. Press 2013).

32. E.g., William D. Nordhaus, Cowles Found. For RESEARCH IN ECON., THE OPTIMAL LIFE OF A PATENT (1967), available at http://cowles.econ.yale.edu/P/cd/d02a/d0241.pdf; see also Paul Klemperer, How Broad Should the Scope of Patent Protection Be?, 21 RAND J. ECON. 113, 120 24 (1990) (explaining how to use microeconomic tools of evaluation to determine patent length); Frederic M. Scherer, Nordhaus' Theory of Optimal Patent Life: A Geometric Reinterpretation, 62 AM. ECON. REV. 422, 424-26 (1972) (discussing the evaluation of static effects).

33. See MACHLUP, supra note 25, at 80 . By the same token, Machlup would not have recommended instituting patent systems in nations that were doing well without them. Id.

34. E.g., Kenneth J. Arrow, Economic Welfare and the Allocation of Resources for Invention, in THE RATE AND DIRECTION OF INVENTIVE ACTIVITY: ECONOMIC AND SOCIAL FACTORS 609, 616-25 (Nat'l Bureau of Econ. Research ed., 1962); FREDERIC M. SCHERER, INNOVATION AND GROWTH: SCHUMPETERIAN PERSPECTIVES 130-91 (MIT Press 1984); SUZANNE SCOTCHMER, INNOVATION AND INCENTIVES 117-18 (MIT Press 2004). 
However, despite the questions, there is significant reason to believe that the weight of analysis lies on the side of patent law generally providing important impetus to valuable innovation. Among other things, nations with laws that strongly protect intellectual property rights exhibit higher growth rates than broadly comparable nations with less IPprotective laws; examination of the central features of patent law suggests that, although they generate some static costs, these features probably generate dynamic benefits that yield social value in excess of their social costs. ${ }^{35}$ The definition of patentable subject matter, the basic requirements for patenting, and essential rules of claim construction, for example, all fit comfortably within a design that is sensitive to dynamic-versus-static cost tradeoffs. ${ }^{36}$ Patent systems also avoid some of the problems associated with more centralized approaches, such as innovation prizes, largely because they elide the need to know in advance with some certainty the value of particular innovations. ${ }^{37}$

Patents do interfere to some extent with follow-on innovation, which becomes more expensive as the volume and breadth of existing patents rises, and the scope of this interference also increases as the significance and novelty of the existing patents rise (characteristics that expand the

35. See, e.g., CASS \& HYLTON, supra note 31 , at 45-46, 50-56, 60-75. See generally ZVI GRILICHES, R\&D AND PRODUCTIVITY: THE ECONOMETRIC EVIDENCE (Univ. of Chi. Press 1998); Charles I. Jones, Growth and Ideas, in 1B HANDBOoK of Economic GrowTH 1063 (Philippe Aghion \& Steven N. Durlauf eds., Elsevier 2005). Some scholars assert that R\&D and productivity have not increased commensurately with the increased strength of patent protections, from which they conclude that patents do not contribute to economic growth. See, e.g., Michele Boldrin \& David K. Levine, The Case Against Patents, (Fed. Reserve Bank of St. Louis, Working Paper No. 2012035A, 2012), available at http://research.stlouisfed.org/wp/2012/2012-035.pdf. These arguments, however, do not account for changes in the ability of firms to evade patent strictures, nor do they consider the tendency of returns in all markets, including markets in innovation, to move toward the competitive equilibrium over time- - phenomena that would limit both investment in R\&D and productivity gains from additional $R \& D$, even if patent rights were important inducements to investment in innovation. See id. In short, the evidence marshaled in these works does not prove the conclusions. See id.

36. See, e.g., CASS \& HYlTON, supra note 31, at 50-75.

37. E.g., id. at 69-70; see also SCOTCHMER, supra note 34, at 39-40; Michael Abramowicz, Perfecting Patent Prizes, 56 VAND. L. REV. 115, 119-27 (2003) (explaining defects in patent prize systems, but endeavoring to create a novel, retrospective alternative mechanism for setting prize levels). 
chances of activity infringing a patent and that decrease the likelihood of finding good substitutes for the patented product or method). ${ }^{38}$ In some settings, these effects may be especially problematic. ${ }^{39}$ At the same time, the ability to profit from a truly novel patent increases with these effects, raising the inducement to invest in (at least certain types of) patenting activity. ${ }^{40}$

Even looking beyond the debate over the general value of patent systems, issues respecting the benefits and costs of some specific aspects of patent law remain. ${ }^{41}$ Four of these are identified in Part II, below, and key concerns that emerge from this set are discussed further in Parts III and IV. As explained in these Parts of the Article, there are legitimate bases for concern about some patent litigation, but many expressed concerns are exaggerated, and some of the most talked about considerations on examination seem much less problematic than frequently asserted. This Article narrows the focus of concern ultimately to two features, particularly identifying patent quality — especially respecting software-as the critical place to make systemic improvement.

\section{SMARTPHONE PATENT FIGHTS}

While academics and other commentators have argued for years about the proper scope of patent protection and best design of patent law, these debates have gained a higher

38. See, e.g., James Bessen \& Eric Maskin, Sequential Innovation, Patents, and Imitation, 40 RAND J. ECON. 611, 611 (2009); Merges \& Nelson, supra note 27 , at $873-75$.

39. See infra note 73 and accompanying text.

40. See, e.g., Ronald A. Cass, Antitrust for High-Tech and Low: Regulation, Innovation, and Risk, 9 J.L. ECON. \& POL'Y 169, 169 (2013); Merges \& Nelson, supra note 27. A similar effect is seen where returns above the competitive level are available for other reasons. See, e.g., Ronald A. Cass \& Keith N. Hylton, Preserving Competition: Economic Analysis, Legal Standards and Microsoft, 8 GEO. MASON L. REV. 1, 36-37 (1999); Nancy T. Gallini, Patent Policy and Costly Imitation, 23 RAND J. ECON. 52 (1992); Jerry R. Green \& Suzanne Scotchmer, On the Division of Profit in Sequential Innovation, 26 RAND J. ECON. 20 (1995); Klemperer, supra note 32. Further, some research suggests that there is actually an increase in diffusion of inventive knowledge from patenting that promotes additional innovative activity. See, e.g., Naomi R. Lamoreaux \& Kenneth L. Sokoloff, Inventors, Firms, and the Market for Technology in the Late Nineteenth and Early Twentieth Centuries, in LEARNING BY DOING IN MARKETS, FIRMS, AND CounTRIEs 19, 23-24 (Naomi Lamoreaux et al. eds., Univ. of Chi. Press 1999).

41. See infra Part II. 
profile-and increased intensity-over the past few years thanks to a series of high-profile patent contests involving smartphones, tablet computers (tablets), and similar mobile computing and communications devices. ${ }^{42}$ To understand why these cases have drawn more commentary and more calls for changes to the patent system, it is necessary to start with the nature of the devices and the litigation.

\section{A. Mobile Devices: Evolving Products, Markets, AND TRADE}

Mobile devices such as smartphones and tablets have become everyday staples for a vast array of tasks: texting, emailing, taking pictures and posting them to social networks, scheduling, calculating, gaming, searching the Internet, reading newspapers, navigating, and much more. 43 The array of different activities that used to be done on a dozen or more devices dedicated to a single task (or closely related set of tasks) have now largely migrated to integrated, portable machines that can perform a wide variety of different tasks. ${ }^{44} \mathrm{~A}$ multitude of products-including Apple's iPhones and iPads, phones and tablets made by HTC, Samsung, Motorola, and many others designed to run on Google's Android platforms, RIM's BlackBerry products, Microsoft-based phones and devices from Microsoft itself or companies such as Nokia, Samsung, and HTC-have become indispensable to business executives, kids on the go, and stay-at-home parents. ${ }^{45}$ In fact, they are relied on in economically advanced nations and, increasingly, in many others, by nearly every type of person and enterprise, at almost every level of affluence, and in an astonishing array of settings.

The change in this field in a very short time has been stunning. Technology that most of us now take for granted would be completely foreign to someone transported twenty-

42. See BoldRIN \& LEVINE, supra note 24, at 15-67, 149-83.

43. See Bengi Korkmaz et AL., MCKinsey \& Co., Cyber Boom: Why TABLET DOMINATION HAS ONLY JUST BEGUN (2012), available at http://www.mckinsey.com/search.aspx?q=Cyber+Boom\%3A+Why+Tablet+Dom ination+Has+Only+Just+Begun\%2C.

44. See id.

45. See, e.g., Nancy Gibbs, Your Life Is Fully Mobile, TIME (Aug 16, 2012), http://techland.time.com/2012/08/16/your-life-is-fully-mobile/ ("It is hard to think of any tool, any instrument, any object in history with which so many developed so close a relationship so quickly as we have with our phones."). 
five years forward from 1987 to 2012. Contrast today's incredibly flexible, feature-packed, complex little devices with Motorola's Dynatac 8000x, the classic mobile phone of the day, famously shown in the 1987 film Wall Street as the device of choice for those at the top of the financial world. 46 The Dynatac served simply as a phone that was not tethered by a cord, weighed about two pounds, could store just thirty numbers, and functioned for only one hour without recharging (a process that took ten hours). ${ }^{47}$ The Dynatac cost nearly $\$ 4,000$, ten to one hundred times the price of phones today (and a far higher multiple if the original cost is translated into equivalent current-dollar terms). 48

Very much unlike the original mobile phones, current mobile devices combine an enormous amount of technological know-how in a small physical space, aggregating enormous numbers of advanced components and methods of operation into products easily fitting in a pocket or purse. ${ }^{49}$ In addition, the products are evolving rapidly in the look and feel of the experiences they deliver and the attractiveness of their presentation. ${ }^{50}$ High-quality video-from games to motion pictures to home creations-now can be seen on small, highly portable screens; sound for songs and speech is now routinely expected with a fidelity that used to be reserved for home sound systems; and every few months, the bar is raised on what consumers expect while the prices of these products continue to fall. 51

46. Sara Breselor, Gordon Gecko's Cell Phone, SLATE (Sept. 23, 2010, 12:07 PM), http://www.slate.com/blogs/browbeat/2010/09/23/gordon_gekko _s_cell_phone.html.

47. Peter Ha, All-Time 100 Gadgets, Communication: Motorola DynaTAC 8000x, TIME (Oct. 25, 2010), http://content.time.com/time/specials/packages larticle/0,28804,2023689_2023708_2023656,00.html.

48. See, e.g., Ross Cantanzariti, The Mobile Phone: A History in Pictures, TECHHIVE (Sept. 29, 2009, 3:10 PM), http://www.techhive.com/article /172837/the_mobile_phone_a_history_in_pictures.html; Ha, supra note 47 . The cost of the Dynatac 8000x in 2012 dollars would be between $\$ 8000$ and $\$ 9000$. Breselor, supra note 46.

49. See Gibbs, supra note 45 ("A typical smartphone has more computing power than Apollo 11 when it landed a man on the moon.").

50. See The Rapid Evolution of Smartphones, PROTECTCELl BlOG (June 1, 2012), http://www.protectcell.com/Blog/June-2012/The-rapid-evolution-of-sm art-phones.aspx.

51. See KoRKMAZ ET AL., supra note 43; Charles Arthur, PC Boom Is Over as Tablets and Smartphones Take Over, Says IDC, GUARDIAN (Aug. 30, 2013, 
As smartphones and tablets have morphed into multifaceted instruments for performing all manner of desired functions, this sector has developed into a booming business. The mobile device sector shipped more than $\$ 200$ billion worth of products in 2011 (some sources put this figure considerably higher), and the total is growing rapidly, amounting to roughly $\$ 500$ billion in 2012.52 In addition, mobile devices and their inputs have become major components of international trade..$^{53}$ Many devices combine technology developed in the United States with components produced in different parts of the world. Production and assembly are largely concentrated in Asia: in China (for Apple), Korea (for Samsung), or Taiwan (for HTC and Microsoft). ${ }^{54}$ Once assembled, the products are sold around the globe, including as imports into the United States. ${ }^{55}$

Annual smartphone sales rose from nearly 500 million units in 2011, to over 700 million units in 2012, to almost one billion units in 2013, and should go well past the billion unit

3:08 PM), http://www.theguardian.com/technology/2013/aug/30/pc-boom-over-t ablets-smartphones.

52. See, e.g., Sarah Perez, Smart Device Shipments Broke Records in Q3 2012, Reaching 303.6 Million Devices, Expected to Grow to 362 Million in Holiday Quarter, TECHCRUNCH (Dec. 10, 2012), http://techcrunch.com/2012/12 /10/smart-device-shipments-broke-records-in-q3-2012-reaching-303-6-million -devices-expected-to-grow-to-362-million-in-holiday-quarter/ (estimating over $\$ 300$ billion for the last two quarters of 2012 and also estimating smartphonetablet market growth to nearly $\$ 800$ billion by 2016 ); Joe Schneider, Australia Judge Calls Apple-Samsung Dispute Over 3G 'Ridiculous,' BlOOMBERG NEWS (Jul. 23, 2012, 2:44 AM), http://www.bloomberg.com/news/2012-07-22/samsung -and-apple-global-patent-fight-moves-to-australia-trial.html (estimating the 2011 handset market figure at $\$ 312$ billion); Victoria Slind-Flor, Samsung, Apple, Disney, Leadscope: Intellectual Property, BloomBerg News (Sept. 24, 2012, 6:00 AM), http://www.bloomberg.com/news/2012-09-24/samsung-apple -disney-leadscope-intellectual-property.html (estimating $\$ 219$ billion for smartphone-tablet market in 2011). The smartphone segment alone accounted for sales exceeding $\$ 338$ billion in 2013. Joel Rosenblatt, Samsung Calls One of Its Own at \$2 Billion Apple Patent Trial, BloOMBERG News (Apr. 14, 2014, 11:01 PM), http://www.bloomberg.com/news/2014-04-14/samsung-calls-one-of -its-own-at-2-billion-apple-patent-trial.html.

53. See, e.g., Eric Mack, Are Any Smartphones Not Made in China?, CNET (Mar. 7, 2012, 3:07 PM), http://www.cnet.com/news/are-any-smartphones-not -made-in-china/ ("For one thing, a smartphone is a complicated device with dozens of components that come from all around the world .... Your phone is truly a global citizen ....”).

54. Id.

55. See infra note 60 and accompanying text. 
mark in 2014. ${ }^{56}$ In fact, sales of Android smartphones alone are expected to exceed one billion units in 2014.57 Smartphone sales worldwide accounted for roughly $\$ 340$ billion in sales in 2013. ${ }^{58}$ While the United States led the charge to smartphones, passing 100 million smartphone owners shortly after the beginning of 2012, China's smartphone base was expected to be roughly half again as large as the United States by the end of 2012; India, the fastest-growing major market for these devices, is predicted to be a close third within the next four years. ${ }^{59}$ U.S. imports of these devices are reported within the category of mobile communications devices, with the most recently available import data running at roughly $\$ 40$ billion annually ${ }^{60}$ (a figure certainly well below the current number).

\section{B. SMARTPHOnE PATENT WARs: What AND Why}

With the array of formerly distinct technologies that are joined in these products comes the potential for contests over

56. E.g., Mark Brownlow, Smartphone Statistics and Market Share, EMAIL MARKETING REP. (Oct. 2012), http://www.email-marketing-reports .com/wireless-mobile/smartphone-statistics.htm; Mark Hamblen, Smartphone Sales Growing by 45\% in 2012, IDC Says, COMPUTERWORLD (Dec. 4, 2012, 2:15 PM), http://www.computerworld.com/s/article/9234314/Smartphone_sales _growing_by_45_in_2012_IDC_says (reporting an estimated 717 million smartphones shipped to vendors during 2012); Felix Richter, Smartphone Shipments to Top 1 Billion in 2014, STATISTA (Mar. 27, 2013), http://www.statista.com/chart/1011/connected-device-shipment-forecast/ (providing figures for 2012 and 2013 sales, and forecasting sales of over 1.5 billion units in 2014).

57. Press Release, Gartner, Gartner Says Worldwide PC, Tablet and Mobile Phone Combined Shipments to Reach 2.4 Billion Units in 2013 (Apr. 4, 2013), available at http://www.gartner.com/newsroom/id/2408515 (projecting 2014 Android shipments at over 1 billion).

58. See, e.g., Rosenblatt, supra note 52.

59. See, e.g., Agence Fr. Press, China to Overtake US as Largest Smartphone Market, India Fourth: IDC, NDTV GADGETS (Aug. 31, 2012), http://gadgets.ndtv.com/mobiles/news/china-to-overtake-us-as-largest -smartphone-market-india-fourth-idc-261341; China Passes 1 Billion Mobile Subscribers, Passes 400 Million Mobile Web Users and Overtakes US as World's Top Smartphone Market, MoBIForge (May 3, 2012), http://mobithinking.com/blog/china-top-mobile-market; Trevor Mogg, US Smartphone Users Now Over 100 Million, Android Increases Market Share, DIGITAL TRENDS (Mar. 6, 2012), http://www.digitaltrends.com/mobile/us-smart phone-users-now-over-100-million-android-increases-market-share/.

60. See, e.g., Press Release, U.S. Census Bureau, U.S. International Trade in Goods and Services, Exhibit 8: Imports of Goods by End-Use Category and Commodity (June 2014), available at http://www.census.gov/foreign-trade /Press-Release/2014pr/06/exh8.pdf. 
the ownership of rights to the innovative products and methods of production they represent. 61 Each mobile device contains at least tens of thousands-probably hundreds of thousands, though it is not clear that the common estimate of 200,000 to 250,000 is accurate 62 of advanced components and methods of operation that are each potentially subject to patent claims. ${ }^{63}$ Inevitably, this has given rise to a series of high-profile legal actions, some of which have become headline news. ${ }^{64}$ Presently, hundreds of cases are pending among the handful of leading companies, some of which are embroiled in large numbers of cases taking place simultaneously (or nearly so) in a dozen or more countries around the globe. ${ }^{65}$ For example, in addition to a very high profile court fight in Silicon Valley, California, Apple and Samsung have been engaged in legal battles in Australia, Japan, Korea, Germany, the United Kingdom, France, Italy, and the Netherlands-as well as before the ITC. 66

Four aspects of the environment that shape the technology and competition in the smartphone and tablet markets come together to create special problems in the ensuing patent cases. ${ }^{67}$ One of these aspects has been considerably noted in this context. ${ }^{8}$ Another has been the focus of extensive debate

61. See infra notes $62-66$ and accompanying text

62. The accepted figure is not necessarily wrong; the problem, instead, is that it is based on a certain amount of guesswork, rarely explained in clear terms. Whatever the right figure, it clearly is a very large one. See, e.g., RPX Corp., Registration Statement (Form S-1), at 59 (Sept. 2, 2011).

63. See infra notes 114-22.

64. E.g., Susan Decker, Kodak Loses Patent Suit Against Apple, RIM on Imaging Patent, BLOOMBERG NeWs (July 20, 2012, 4:44 PM), http://www.bloomberg.com/news/2012-07-20/kodak-loses-case-against-apple -rim-on-imaging-patent.html; Ashby Jones \& Jessica E. Vascellaro, Apple v. Samsung: The Patent Trial of the Century, WALL ST. J. (Jul. 24, 2012, 1:01 PM), http://online.wsj.com/news/articles/SB10000872396390443295404577543 221814648592.

65. See infra note 66 and accompanying text.

66. See Scott Martin, Consumers Likely to Feel Apple Defeat of Samsung, USA TODAY (Aug. 27, 2012, 3:45 PM), http://usatoday30.usatoday.com/tech /news/story/2012-08-25/apple-samsung-patent-trial-impact/57332198/1; Steven J. Vaughan-Nichols, Apple's Worldwide War on Samsung and Android, ZDNET (Nov. 30, 2011, 9:09 AM), http://www.zdnet.com/blog/open-source /apples-worldwide-war-on-samsung-and-android/9945.

67. See infra notes $72-108$ and accompanying text.

68. See infra notes $72-78$ and accompanying text. 
in relation to a different set of cases. ${ }^{69}$ The two other aspects are observed in passing, but less frequently addressed as core problems in the current patent wars. ${ }^{70}$

First, the technology simply offers an extraordinary number of opportunities for fights over who is infringing whose legal rights. Designs are complicated, many different components and methods of operation are joined together, and the number of different patent claims potentially implicated in the devices makes every device a potential infringement of someone else's patent rights. ${ }^{71}$ The creator of any of these devices, hence, confronts what critics of the current system have dubbed a "patent thicket"-and, unlike Br'er Rabbit's story, this thicket is not one the designers and producers see as a safe haven. ${ }^{72}$

In most settings where companies have potentially offsetting claims against one another, accommodations will be worked out with cross-licensing arrangements rather than spending the time, money, and energy to litigate the underlying legal and factual issues. ${ }^{73}$ Where so very many

69. See infra notes 79-84 and accompanying text.

70. See infra notes $85-108$ and accompanying text.

71. See infra notes $115-23$ and accompanying text.

72. E.g., BESSEN \& MeURER, supra note 11, at 120-32; Carl Shapiro, Navigating the Patent Thicket: Cross Licenses, Patent Pools, and StandardSetting, in 1 InNovation Policy AND The EConomy 119 (Adam B. Jaffe et al. eds., MIT Press 2001); Michael A. Heller \& Rebecca S. Eisenberg, Can Patents Deter Innovation? The Anticommons in Biomedical Research, 280 SCIENCE 698, 698-701 (1998) (highlighting the problem in a biomedical context); Adam Mossoff, The Rise and Fall of the First American Patent Thicket: The Sewing Machine War of the 1850s, 53 ARIZ. L. REV. 165 (2011); James Bessen, Patent Thickets: Strategic Patenting of Complex Technologies, (Research on Innovation, Working Paper No. 0401, 2004), available at http://www.researchoninnovation.org/thicket.pdf.

73. E.g., Shapiro, supra note 23. Even where parties initially see an advantage in litigating patent claims, once the outlines of likely judicial dispositions become clear, parties with competing claims are likely to settle through cross-licensing or cross-licensing-plus deals. This helps explain the recent rash of settlements for companies holding different patents on technologies used in smartphones and related products. See, e.g., Simon Johnson, Samsung to Pay Ericsson \$650 Mln Plus Royalties to End Patent Spat, REUTERS (Jan. 27, 2014, 7:48 AM), http://www.reuters.com/article /2014/01/27/ericsson-samsung-idUSL5N0L10H620140127; Lee \& Cheng, supra note 16; Min-Jeong Lee \& Don Clark, Samsung, Cisco Sign Cross-License Pact for Tech Patents, WALL ST. J. (Feb. 5, 2014, 4:30 PM), http://www.wsj.com /articles/SB10001424052702304680904579365220297306100; Parnell, supra note 16 
firms might have patented technology embedded in the product, however, and where the value of different collections of property rights can be quite disparate, such accommodations cannot always be arranged. The costs of identifying the potential patent claims and rights owners, the validity of the claims, the likelihood that a claim is infringed and of negotiating with the various owners of potentially infringed claims in these settings often could exceed the value of the product itself. ${ }^{74}$ While cross-licensing agreements covering broad classes of innovations among likely holders and users of patented technologies are the general answer to the problems associated with these administrative costs, this approach will not necessarily be availing if all the patented methods and components from all the potential claimants are not included. ${ }^{75}$

The potential for problems in negotiating practical accommodations is exacerbated when one party enjoys a particular, significant market advantage because of a given feature arguably protected by patent rights or when one of the parties is neither a holder of patent rights nor producer of the products. ${ }^{76}$ Recognition of this point has led to a growing concern with the role of non-practicing entities (NPEs), expressed by, among others, Justices Kennedy, Stevens, Souter, and Breyer in eBay Inc. v. MercExchange, L.L.C. ${ }^{77}$ This concern is discussed in Part III.

A second problem in these cases is that the rapid evolution of the products, with new features constantly being added and old features updated, makes it both more likely that there will be potential new infringement claims and more likely that old infringement claims may be outdated by the time the litigation is concluded or shortly afterward. ${ }^{78}$ Even relatively slow

74. While many commentators looking at this sector have emphasized the problems facing innovators who confront large numbers of potential patent claims, it also is worth noting that past innovators also faced problems in this setting, as the administrative costs of enforcement also may be large relative to the gains. See, e.g., Christina Mulligan \& Timothy B. Lee, Scaling the Patent System, 69 N.Y.U. ANN. SURV. AM. L. 289, 289-97 (2012).

75. See generally U.S. DEP'T OF JUsTICE \& FED. TRADE COMM'N, ANTITRUST ENFORCEMENT AND INTELLECTUAL PROPERTY RIGHTS: PROMOTING INNOVATION AND COMPETITION, ch. 3 (2007).

76. See infra Part III; see also infra note 77.

77. See, e.g., eBay Inc. v. MercExchange, L.L.C., 547 U.S. 388, 395-96 (2006) (Kennedy, Stevens, Souter \& Breyer, J.J., concurring).

78. See infra Part III. 
changes in this sector occur at a fairly rapid rate by ordinary industry standards. ${ }^{79}$ Apple, a company well-known for taking a longer time for its new product releases, still has been updating and altering its iPhone series on an annual basis, while many other mobile device manufacturers have released new models on a much faster pace, at times coming out with new products every few months. 80

The very rapidity of change in the mobile device sector is in one sense a strong inducement to file claims, especially if the relief available encompasses the exclusion of infringing products from sale in a key market such as the United States. ${ }^{81}$ Because the product cycles are relatively short, the costs associated with being excluded from the market for even a fairly short time are relatively high. ${ }^{82}$ Demand for a given product is quite time-limited, and market leadership can change quickly, as firms like Nokia, Motorola, and RIM, among others, have discovered. ${ }^{83}$ For the same reason, the costs from having to compete against an infringing product for even a fairly short time also can be high. From both sides of an infringement claim, then, there is a special sensitivity to both the impact of an injunction or exclusion order and the effect of its timing.

Third, at least some parts of the mobile device sector (particularly at the platform level), exhibit a winner-take-most quality. ${ }^{84}$ Rather than maintaining even fragmentation among

79. See infra note 80 and accompanying text.

80. E.g., Eric M. Zeman, HTC Commits to Upgrading 7 Smartphones to Android 4.0, PHONESCOOP (Nov. 7, 2011, 10:28 AM), http://www.phonescoop.com/articles/article.php?a=9231 (discussing HTC product updates); Tong Zhang, IDC: Smartphone Market Growth Strong; Samsung Leads Apple, MoBILETECHREVIEW FORUM (July 27, 2012, 9:55 AM), http://www.mobiletechreview.com/ubbthreads/showflat.php?Number=43052.

81. See infra Part III.

82. See infra Part III.

83. E.g., Evan Niu, Visualized: The Rise and Fall of Nokia and RIM at the Hands of Apple, MOTLEYFoOL (July 2, 2012), http://www.fool.com /investing/general/2012/07/02/visualized-the-rise-and-fall-of-nokia-and -rim-at-t.aspx; Peter Svensson, In Fall Apple Season, Rival Phone Makers Struggle, YAHOO! NEWS (Sept. 5, 2012, 7:14 PM), http://news.yahoo.com /fall-apple-season-rival-phone-makers-struggle-220719157--finance.html.

84. For a discussion of the role of winner-take-most markets in another context, see, for example, Nicholas Economides, The Microsoft Antitrust Case: Rejoinder, 1 J. INDUSTRY COMPETITION \& TRADE 7-15 (2001); S. J. Liebowitz \& Stephen E. Margolis, Network Externality: An Uncommon Tragedy, 8 J. ECON. PERSP. 133 (1994). 
many types of platforms, the mobile device markets seem to shift substantially toward one dominant platform-at different times Symbian's operating system (used by Nokia), Apple's iOS, or Google's Android operating system (or, in sales to businesses, the BlackBerry OS) - as technologies (and products built on them) evolve. ${ }^{85}$

To some extent, a large market share for the market leader in this sector reflects classical economic factors such as scalerelated returns on large investments in technology, including its design, needed to make an operating system (and products based on it) work well for the complex set of consumer demands each of these devices must satisfy. ${ }^{86}$ Another explanation for large market share relies on the value of the whole ecosystem, not simply one aspect such as the particular device or specific quality of a version of the operating system, but the whole set of applications and related devices that operate best with it. 87 This was the argument for Microsoft's dominance in the PC realm for so many years, advanced both by those who saw that dominance as a threat to competition and by those who saw it as a transitory (and efficient) characteristic of this sort of market. 88

While technical explanations for market dominance focused on economies of scope and scale doubtless capture some of what accounts for changes in the mobile device sector, these are not wholly satisfactory explanations. ${ }^{89}$ Other factors, such as shifts in consumer taste and the degree of consumer

85. See, e.g., Kofi Bofah, Research in Motion Is Trading Off Hope, SEEKING ALPHA (Jan. 10, 2013, 12:06 PM), http://seekingalpha.com/article /1105341-research-in-motion-is-trading-off-hope (suggesting a smartphone market in which two systems dominate).

86. See, e.g., Michael L. Katz \& Carl Shapiro, Systems Competition and Network Effects, 8 J. ECON. PERSP. 93, 93-95 (1994); Bofah, supra note 85 (discussing Apple's and Android's dominance of the smartphone market).

87. See Katz \& Shapiro, supra note 86, at 93-94.

88. E.g., Michael L. Katz \& Carl Shapiro, Antitrust in Software Markets, in Competition, INNOvation AND THE Microsoft Monopoly: ANTIRUsT IN THE DigitAL MARKETPLACE 29-31 (Jeffrey A. Eisenach \& Thomas M. Lenard eds., Kluwer 1999); John E. Lopatka \& William H. Page, Microsoft, Monopolization, and Network Externalities: Some Uses and Abuses of Economic Theory in Antitrust Decision Making, 40 ANTIRUST BULL. 317, 333, 335-40 (1995); William H. Page, Microsoft and the Limits of Antitrust, 6 J. Competition L. \& ECON. 33, 37-40 (2010); Richard Schmalensee, Antitrust Issues in Schumpeterian Industries, 90 AM. ECON. REV. 192 (2000).

89. Katz \& Shapiro, supra note 86, at 94. 
commitment to the systems themselves also play roles in the results observed in this sector. ${ }^{90}$ Even though consumers do switch from one system or platform to another, there is resistance to such change, evidenced by surveys showing high levels of consumer loyalty. ${ }^{91}$ But there also is a strong pull toward the leading platform and the most popular devices that would not be observed without consumers abandoning one platform or product group to embrace a currently more attractive one. ${ }^{92}$

Fourth, some (perhaps many) of the components and methods of operation that are combined in these products are strained fits with the core principles of the patent system-in some cases, likely failing to satisfy central requirements of the patent system as traditionally understood.93 Design features for smartphones and tablet computers, at least at present, are selected from a limited array of options, even though the ways in which particular features are combined and the specific mechanisms for implementing some of them leave scope for innovation. ${ }^{94}$ For example, Apple received a patent covering the use of a rectangular shape with rounded corners for the design of a smartphone. ${ }^{95}$ This was a major attribute of one of Apple's

90. See id. at 93-95, 109 (explaining how consumers benefit by only using one network); see also Mary Beth Quirk, Apple \& Amazon Top This Year's Brand Loyalty Survey, Blackberry Hangs on in Last Place, CONSUMERIST (Oct. 26, 2012), http://consumerist.com/2012/10/26/apple-amazon-top-this-years -brand-loyalty-survey-blackberry-hangs-on-in-last-place/ (discussing how Apple is rising in popularity as Blackberry is falling in popularity).

91. Quirk, supra note 90.

92. See, e.g., Michael Kan, Samsung Smartphone Sales Surge, Apple Gets a Tiny Boost from iPhone 5s, TECHHIVE (Nov. 14, 2013, 2:10 AM), http://www.techhive.com/article/2063540/samsung-smartphone-sales-surge -while-apple-gets-a-small-boost-from-iphone-5s.html.

93. See infra notes 94-102 and accompanying text.

94. See Joel R. REIDENBERG \& JAMELA DEBELAK, CTR. ON LAW \& INFO. Policy, The IMPACT OF THE ACQUISITION AND UsE OF PATENTS ON THE SMARTPHONE INDUSTRY 21-25 (2012), available at www.wipo.int/export /sites/www/ip-competition/en/studies/clip_study.pdf.

95. E.g., Chris Foresman, Apple Awarded Design Patent for Actual Rounded Rectangle, ARS TECHNICA (Nov. 7, 2012, 11:15 AM), http://arstechnica.com/apple/2012/11/apple-awarded-design-patent-for-actual -rounded-rectangle/. Although its consistency with patent law will no doubt be debated, this patent grants clearer protection to the design features that were claimed by Apple under two different patents (U.S. Patent No. 504,889 (filed Mar. 17, 2004), U.S. Patent No. 593,087 (filed July 30, 2007)) in the litigation with Samsung. Id.; Steve Wildstrom, Pinch-to-Zoom and Rounded Rectangles: 
design patents asserted in the litigation against Samsung.96 The rectangular-shape-with-rounded-corners claim was not ultimately the basis for the California jury's award, 97 but the grant of a patent for what seems so obviously one of the more likely choices for the shape of these products exposes some of the difficulties with design patent protections in fields like the mobile device sector. ${ }^{98}$

More importantly, technical patents (the "utility" patents at the core of all patent systems) also present problems in the smartphone sector. ${ }^{99}$ In part, the problem here is the difficulty of finding the novelty and nonobviousness required for utility patents when so many different claims are made on so narrow a range of technical considerations. 100 The problem is not that the case for patent protection as a spur to innovation is lower in this area because so many of the advances most important to smartphone and tablet functioning have already been made, or because producers of these products in large measure distinguish their offerings not by leaps in innovation but by design, marketing, and smaller innovative steps. ${ }^{101}$ There are

What the Jury Didn't Say, TECH.Pinions (Aug. 29, 2012), http://techpinions.com/pinch-to-zoom-and-rounded-rectangles-what-the-jury -didnt-say/9465.

96. E.g., Ed Burnette, The Verdict Is in: Samsung vs. Apple, ZDNET (Aug. 25, 2012), http://www.zdnet.com/the-verdict-is-in-samsung-vs-apple-700000 3163/; Wildstrom, supra note 95 (describing the treatment of patent claims covering rectangular shape and rounded corners for the iPad, under design patent U.S. Patent No. 504,889 (filed Mar. 17, 2004), and for the iPhone, under design patent U.S. Patent No. 593,087 (filed July 30, 2007)).

97. Burnette, supra note 96.

98. See Foresman, supra note 95 (describing the Apple design as "a literal rounded rectangle"); Anna Leach, Apple Is Granted a Patent on the Rectangle. No, Really, REGISTER (Nov. 8, 2012), http://www.theregister.co.uk/2012 /11/08/apple_rectangle_rounded_corners/.

99. See REIDENBERG \& DEBELAK, supra note 94 (using Apple as an example to note how new entrants to the cellphone market dramatically increase their patent portfolios, which include utility patents).

100. See id. at 13-16 (highlighting the increase in patent grants in the cellphone market).

101. E.g., Charles Duhigg \& Steve Lohr, The Patent, Used as a Sword, N.Y. TIMES, Oct. 8, 2012, at A1 (quoting Judge Richard Posner); James Kendrick, Has Smartphone Technology Hit the Wall?, ZDNET (Apr. 18, 2011, 6:31 PM), http://www.zdnet.com/blog/mobile-news/has-smartphone-technology-hit-the -wall/1987; David Talbot, The New Smartphone Incrementalism, MIT TECH. REV. (Sept. 7, 2012), http://www.technologyreview.com/news/429117/the-new 
still many advances to make in this arena-in materials and other components, in methods of operation, and in arrangement of matter to create new options for the devices-and often these will be secured only through the sort of investments that intellectual property rights stimulate and reward. 102

Instead, the problem in relation to the patents affecting smartphone and tablet design and production is that the quality of at least some patent grants is questionable, and that lax standards in this setting magnify difficulties in a system that cannot be error free. ${ }^{103}$ The "impacted" quality of the patents implicated in the production of smartphones and related devices, together with the short product cycles, high returns to leaders, and low quality of many (though surely not all) patents, creates a significant potential for "hold-up" problems if the legal system does not accurately and predictably sort through the legal claims. ${ }^{104}$ While there is a strong case for patent protection for novel inventions, protection for inventions that do not represent significant advances (inventions that do not in fact meet the tests for patent grant) generates costs without compensating social benefit. 105 The risk of a crippling damage award or injunction that takes a key product off the market to protect a patent claim of dubious merit is both especially serious in this setting and especially likely, making the expected error costs of a generally effective patent system far higher here than in much of patent litigation. ${ }^{106}$ That may explain why such a high

-smartphone-incrementalism/ (explaining how the present cellphone market is "less about dramatic breakthroughs... and more about gaining market buzz").

102. See generally Duhigg \& Lohr, supra note 101 (quoting a statement from a former Apple Executive: "If we can't protect our intellectual property, then we won't spend millions creating products like the iPhone").

103. Id. (noting that the patent office is "overworked, understaffed ... [and that] some of their work is subjective").

104. E.g., Michael Risch, Software Patents and the Smartphone, PRAWFSBLAWG (Nov. 15, 2012, 10:39 AM), http://prawfsblag.blogs.com/2012 /11/software-patents-and-the-smartphone.html. For a discussion on the relation of the problematic nature of low patent quality to error rates and types in dispute resolution, see infra Part III.

105. See Lohr, supra note 4 ("[S]martphone patent battles are enabled by lots of trivial patents . . . In the end, consumers may be the losers.").

106. See id. ("Smartphones are very different. An infringement ruling can slow a rival down for a few months ...."). 
proportion of patent litigation targets makers of smartphones and related devices. ${ }^{107}$

\section{TROLLING FOR ANSWERS IN THE THICKET}

\section{A. New or Used: Solutions to the SMartphone Patent PROBLEM}

While the four factors described in Part II taken together explain why the smartphone patent wars have broken out and why there is widespread concern about them, finding solutions requires something more. After all, some aspects of the mobile device business that contribute to the problems seen in the smartphone wars-the complexity and rapid evolution of products, for example-are neither subject to change through the legal system nor suitable bases for altering the basic rules that currently guide that system. ${ }^{108}$

The attributes of the smartphone business that affect patent litigation need to be understood for what they say about the broader patent (and patent dispute) system rather than seen as reasons for creating a special set of rules. This is true because without understanding the roles played by the different factors, it is not possible to appreciate what changes might be helpful or to have a sound basis for deciding which firms, types of patents, or types of disputes should qualify for special treatment. ${ }^{109}$ More generally, most efforts to address problems in one area of the law identified by a set of intuitively selected characteristics through creation of separate rules-for the mobile device sector or for firms in sectors where products change quickly, for instance-commonly can be expected to raise administrative costs and to generate additional problems. ${ }^{110}$

107. E.g., id. (describing how patent litigation follows "every industrial innovation," but the smartphone market is "bigger, global and unusually complex").

108. E.g., Risch, supra note 104 . These features, however, certainly would inform application of the rules, for example in the calculation of damages for infringement and in the evaluation of requests for particular forms of injunctive relief under the four-factor test reiterated in eBay Inc. $v$. MercExchange, L.L.C., 547 U.S. 388, 390 (2006).

109. See Frank H. Easterbrook, Cyberspace and the Law of the Horse, 1996 U. CHI. LEGAL F. 207, 208 (arguing that it is unknown if certain features of the existing intellectual property laws are optimal).

110. See id. at 215-16. 
Judge Frank Easterbrook has driven this point home by analogy to the notion of crafting a distinct "law of the horse" (a metaphor he attributes to former Chicago Dean and Stanford President Gerhard Casper) in place of reliance on generally applicable doctrines of tort, contract, and so on, to deal with the plethora of legal problems that came with the roles of horses in Western societies. ${ }^{111}$ As Judge Easterbrook has explained in answering calls for a special law of cyberspace, rules often can be tailored to fit changes in the nature of cases and can shift between more specific rule-type and more abstract standardtype approaches, but problems that arise in new contexts almost always are resolved better through the application of existing legal constructs instead of creating new ones wholesale. ${ }^{112}$

Instead of separate rules, looking for answers to the smartphone patent wars requires sorting through the asserted problems to see which characteristics of the patent system, the entities interacting with it, or the mechanisms for resolving disputes about it are truly problematic and which legal rules can be addressed effectively without causing more harm. ${ }^{113}$ This Part and Part IV are preliminary efforts in that vein.

\section{B. That's THE THICKET: TRANSACTION COSTS AND HOLD-UpS}

The predicate for concerns about patents in the smartphone sector is the notion that there is a patent thicket, a large number of overlapping patents in the same technological space. ${ }^{114}$ Adam Mossoff summarizes the concerns associated with this phenomenon: a patent thicket "increases transaction costs, accentuates hold-out problems, and precipitates costly

\section{Id. at $207-08$.}

112. See id. at 207-08, 215-16 ("[T] he best way to learn the law applicable to specialized endeavors is to study general rules."). On movement (and tradeoffs) between rule-based and standard-based approaches, see, for example, FREDERICK SCHAUER, Playing BY THE RUles: A PHILOSOPHICAL EXAMINATION OF RULE-BASED DECISION-MAKING IN LAW AND LIFE 137-45 (1991); Colin S. Diver, Optimal Precision of Administrative Rules, 93 YALE L.J. 65 (1983); Isaac Ehrlich \& Richard A. Posner, An Economic Analysis of Legal Rulemaking, 3 J. LEGAL STUD. 257 (1974); Louis Kaplow, Rules Versus Standards: An Economic Analysis, 42 DUKE L.J. 557 (1992).

113. See infra Parts III, IV.

114. See Shapiro, supra note 72, at 119-22. But see Mossoff, supra note 72, at 204-05 (emphasizing other cost-related issues that might be used to define a patent thicket, irrespective of the number of overlapping patents). 
litigation, which prevents commercial development.... Additionally, a patent thicket can block new research into follow-on inventions." 115

The transaction cost (or administrative cost) problem exists because of the time, effort, and expense that would be needed to identify all the patent claims that might be infringed, evaluate the probability that specific patent claims are both valid and infringed, assess whether to use alternative methods of operation or substitute components to avoid the possible infringement, find the holders of the patent rights, and negotiate licenses for particular uses of the patented items or methods. ${ }^{116}$ These costs are apt to rise exponentially with the number of potential patent claims and rise as well with the difficulty of sorting through potential claims (an issue tied, among other things, to problems associated with resolution of questions of novelty and nonobviousness of claimed inventions in an innovation space with many overlapping claims). ${ }^{117}$ It is no surprise that this is a special problem in the context of smartphones and similar mobile devices, given the extensive array of complicated technologies combined in them. ${ }^{118}$

The hold-up problem is that each patent holder who seeks to enforce patent rights has the prospect of stopping sales of the accused products. ${ }^{119}$ That threat, in turn, allows each enforcing entity to potentially extract the full value of the sales loss during whatever time an accused product would be off the

115. See Mossoff, supra note 72, at 167 (describing, but not endorsing, claims respecting problems of patent thickets).

116. The term "transaction cost" as used here includes costs sometimes separately labeled "information costs." E.g., Clarisa Long, Information Costs in Patent and Copyright, 90 VAND. L. REV. 465, 465-71 (2004).

117. Novelty and nonobviousness are core elements of patentability. CASS \& HYLTON, supra note 31 , at 63-69.

118. See, e.g., Risch, supra note 104 (noting that the devices include, among other things: "a general purpose computer and all that comes with it (CPU, RAM, I/O interface, operating system, etc.); active matrix display; touch screen display; cellular voice technology; 1x data networking; $3 \mathrm{G}$ data networking; 4G data networking; Wi-Fi data networking; Bluetooth data networking; GPS technology (and associated navigation); accelerometer technology; digital camera (including lens and image processing); audio recording and playback; battery technology; [and] force feedback technology (phone vibration and haptic feedback)") (punctuation and capitalization altered from original).

119. See Mark A. Lemley \& Carl Shapiro, Patent Holdup and Royalty Stacking, 85 TEX. L. REV. 1991, 2008-09 (2007). 
market. ${ }^{120}$ The risks that come with efforts to assemble a product from a large number of patented or patentable components and methods owned by different patentees is analogous to the risk that attends efforts to assemble a large amount of land for a development project when the land is owned by many different people. In the land development context, a single landholder holding out for a higher payment in theory can extract the full value represented by all holders of parcels needed for the project-which is the now-standard explanation for allowing governments to take property by eminent domain (subject to provision for reasonable compensation). ${ }^{121}$ In the patent context, this hold-up risk rises sharply with the number of patents and patent holders. ${ }^{122}$

\section{Patent Pools AND Cross-Licenses}

Despite the issues associated with patent thickets, and the considerable amount of attention it has drawn in the scholarly literature, that feature in itself is not apt to point toward a solution to the smartphone patent wars. In part, focusing on problems of patent thickets is not likely to be rewarding because there is little chance of avoiding a thicket of some dimension in the smartphone arena. ${ }^{123}$ This focus also is not likely to yield returns to policymakers because, as with many problems that are extremely scary in theory, the most obvious problems associated with patent thickets already have been significantly tamed in practice.

120. Id. at 2001-02.

121. See, e.g., Richard A. Epstein, Takings: Private Property AND THE Power OF EMINENT DomaIn (Harvard Univ. Press 1985) (explaining the basis for eminent domain powers as a cure for hold-up risks). The analogy between the two settings is illustrative but imperfect, as the hold-up risk comes at different junctures; that the potential for a hold-up after a complex product incorporating many different patented components and methods is on the market does not necessarily imply similarly strong bargaining power for the various patentees at the time a product is being designed. See Einer Elhauge, Do Patent Holdup and Royalty Stacking Lead to Systematically Excessive Royalties?, 4 J. COMPETITION L. \& ECON. 535, 568 (2008). But the same is true in different measure for land development projects as well, given the developer's ability to select different sites ex ante. See EPSTEIN, supra.

122. See Lemley \& Shapiro, supra note 119, at 2044, 2046-48 (describing the "royalty stacking" problem that comes from hold-up with multiple patentees enforcing patent rights respecting the same end-product).

123. See, e.g., Risch, supra note 104 (listing the many features and technologies involved in cellphones). 
Two dominant means of dealing with transaction cost and hold-up problems in similar settings have been used for many years. One is for firms holding patents for products and processes that are useful parts of larger, complex products to share the patents in patent pools that allow a set of firms to use any patented product or process, under what is essentially a type of blanket license, without need for separate negotiation and individualized consent. ${ }^{124}$ The other is for firms holding the patents to cross-license their patent portfolios (or at least categories of patents within that portfolio), agreeing either not to charge one another for infringing uses of the patents or to allow broad categories of use, perhaps with a side payment if one firm's patents are significantly more valuable than another's. 125 Neither mechanism requires specification of individual patent claims, of the uses covered, or of payments owed for specifically identified infringements, greatly reducing the transaction costs of dealing with large numbers of potentially infringed patents and simultaneously reducing litigation threats. ${ }^{126}$

Professor Carl Shapiro recognizes that there are practical ways for the problems associated with patent thickets to be solved (or at least significantly ameliorated) by would-be users and patent holders, but worries that overly aggressive antitrust enforcement can "mak[e] it difficult for patentees possessing complementary and potentially blocking patents to coordinate to engage in cross licensing, package licensing, or to form patent pools." 127 The problem that concerns antitrust authorities is that the pools and cross-licenses can encompass

124. See Robert P. Merges, Institutions for Intellectual Property Transactions: The Case of Patent Pools, in EXPANDING THE BOUNDARIES OF INTELLECTUAL PROPERTY: INNOVATION POLICY FOR THE KNOWLEDGE SOCIETY 123, 129-33 (Rochelle Cooper Dreyfuss et al. eds., Oxford Univ. Press 2001); Jeffrey Fromm, Senior Mgmt. Counsel, Hewlett-Packard, Address at the Department of Justice Antitrust Division and Federal Trade Commission Hearings on Competition and Intellectual Property Law and Policy in the Knowledge Based Economy: Cross-Licensing and Patent Pools 17 (Apr. 17, 2002), available at http://www.ftc.gov/sites/default/files/documents/public _events/competition-ip-law-policy-knowledge-based-economy-hearings/020417 trans.pdf.

125. See, e.g., Fromm, supra note 124.

126. See, e.g., id. at 255,274 ("Obviously we don't want to turn this into another form of litigation. That's not the purpose of pools. It is to avoid litigation.").

127. Shapiro, supra note 72 , at 144 . 
substitute products or processes as well as complementary products or processes, allowing firms to use these mechanisms as tools for suppressing competition rather than merely lowering costs to make competition more efficient. ${ }^{128}$ Antitrust enforcers are rightly concerned about this potential, but the obvious utility of cross-licensing and voluntary patent-pooling to solving transaction cost problems in a range of settings should counsel enforcers generally to resist challenging this conduct. ${ }^{129}$ Excessive enforcement activity (including investigations as well as prosecutions) undoubtedly will discourage socially beneficial uses of these mechanisms. ${ }^{130}$ Fear of unduly aggressive antitrust enforcement is not limited to this context, but-because agreement among competing or potentially competing firms is likely -it may present special concerns for enterprises contemplating patent pools or crosslicenses. ${ }^{131}$

In contrast to Professor Shapiro, James Bessen contends that even if the hold-up and transaction cost problems can be solved and there are no concerns about excessive antitrust activity, patent thickets still discourage innovation. ${ }^{132}$ His argument, based on calculation of the optimal willingness of industry leaders to cross-license in stylized market settings, is that in markets characterized by low patent standards and low returns to innovative first-movers, patent thickets will develop and cross-licensing will actually reduce returns to innovation

128. See, e.g., U.S. DEP'T OF JUSTICE \& FED. TRADE COMM’N, supra note 75, at 74-77 (discussing substitutes within a patent pool); Joel I. Klein, Acting Assistant Attorney Gen. Antitrust Div., U.S. Dep't of Justice, Address Before the American Intellectual Property Law Association: Cross-Licensing and Antitrust Law (May 2, 1997), available at http://www.justice.gov/atr/public /speeches/1118.htm ("I also believe that there are some cross-licenses in place now that, had we been aware of them at the time of their inception, we might have sought to block under the antitrust laws.").

129. See Klein, supra note 128, at 3 ("I would expect that by far most crosslicenses and pools are, on balance, procompetitive.”).

130. See, e.g., Shapiro, supra note 72, at 119 ("Antitrust law and enforcement, with its historical hostility to cooperation among horizontal rivals, can easily add to these transaction costs."); Fromm, supra note 124; see also Cass, supra note 40, at 191-99 (discussing the role of excessive inclination to initiate investigations in discouraging desirable business conduct).

131. See Klein, supra note 128 , at 3 (discussing that two competing firms may have an incentive to cross-license at the expense of the public).

132. Bessen, supra note 72, at 17-20. 
below the ideal level.133 Contrary to the more frequently expressed complaints that patent thickets stifle innovation by handcuffing new firms that cannot efficiently negotiate their way around the mass of existing patents, this work suggests that patent thickets stifle innovation by encouraging excessive cross-licensing. ${ }^{134}$

The academic literature, thus, argues that patent pools and cross-licensing may be bad either because they occur too frequently or because they do not occur frequently enough (a kind of reverse "Goldilocks" problem). ${ }^{135}$ Notwithstanding the scope of the criticism, there is little concrete evidence that problems associated with these problem-solving arrangements carry social costs greater than their benefits. ${ }^{136}$ Further, the "damned if you do, damned if you don't" character of arguments against cross-licensing and patent pooling suggests that the case for changes to the law to discourage cross-licensing or voluntary patent pooling is far from securely establishedotherwise the two sets of arguments against these practices would not work at cross purposes. 137

Similar weakness affects much of the argument that substantial changes in the law are needed to reduce the costs of patent thickets as a general proposition, apart from other attributes of the particular litigants, patents, or specific elements in dispute (for example, by restricting patent

133. Id.

134. Id. at 1-4, 18-20; see also Tim Worstall, Does Apple's HTC Patents Settlement Doom the Samsung Case?, ForBES (Nov. 17, 2012, 12:57 PM), http://www.forbes.com/sites/timworstall/2012/11/17/links-17-nov-does-apples-h tc-patents-settlement-doom-the-samsung-case/ (highlighting the substantial licensing deal between Apple and HTC).

135. Compare Bessen, supra note 72, at 17-20 (suggesting cross-licensing occurs too frequently), with Shapiro, supra note 72 , at 144 (expressing concerns that regulation may cause cross-licensing to occur too infrequently).

136. See Shapiro, supra note 72 , at 126-30, 134-36 (discussing the numerous benefits offered by patent pools and cross-licensing).

137. Explanations of the role that patent pools and cross-licensing play in reducing the ill-effects of patent thickets, together with indications that royalty-setting arrangements may differ significantly from those assumed in theories supporting complaints about the effects of patent thickets, make the case that more needs to be done to establish a basis for altering present rules. E.g., Elhauge, supra note 121; Merges, supra note 124; Doug Lichtman, Patent Holdouts in the Standard-Setting Process (Univ. Chi. Law Sch. Working Paper No. 292, 2006), available at http://www.law.uchicago.edu/ files/files/292.pdf; Fromm supra note 124. 
remedies). ${ }^{138}$ This argument subsumes the claim that the proposed changes would pose little risk of collateral harm to innovation and an economy increasingly based on innovation. ${ }^{139}$ Academic speculations on the subject are interesting and in some respects instructive, but their conclusions depend heavily on the assumptions that each author makes at the outset. ${ }^{140}$ Costs of the current regime are hard to quantify and so are the costs of altering the regime, whether by limiting opportunities to engage in the most common cooperative arrangements or by restricting litigation rights. ${ }^{141}$

138. See, e.g., James Boyle, Open Source Innovation, Patent Injunctions, and the Public Interest, 11 DUKE L. \& TECH. REV. 30, 59-61 (2012) (suggesting the ITC should limit the use of injunctive remedies); Heller \& Eisenberg, supra note 72; Lemley \& Shapiro, supra note 119, at 1992-95 (describing how a threat of injunction greatly increases negotiating power).

139. The point made in the text-that much of the cost-benefit analysis of changing the law is as of now indeterminate-does not reach possible administrative changes in patent awarding that might be made even without changes to the patent law in order to address concerns about patent quality, changes that, in addition to strengthening patent quality, might reduce the density of patent thickets. See infra Part IV. Even with a significant change in patent standards implemented through the U.S. Patent \& Trademark Office, however, devices such as smartphones inescapably will be embedded in patent thickets-these devices simply incorporate too many complicated and interrelated technologies to avoid that outcome. See, e.g., Risch, supra note 104 (listing many of the features contained in a typical cellphone).

140. That point is made especially clear in Elhauge, supra note 121, at 537, with respect to one of the foundational pieces in the patent thicket literature. Of course, sensitivity to background assumptions is not peculiar to this specific literature; in analysis of almost any complicated social phenomenon (which, almost by definition, is not subject to actual testing in the same manner as many physical phenomena), framing assumptions play a critical role. See, e.g., Günter Knieps \& Ingo Vogelsang, The Sustainability Concept Under Alternative Behavioral Assumptions, 13 BELL J. ECON. 234, 235 (1982) (exploring the Bertand assumption as it relates to sustainability); Michael Spence, Contestable Markets and the Theory of Industry Structure: A Review Article, 21 J. ECON. LITERATURE 981 (1983) (reviewing WILLIAM J. BAUMOL ET AL., Contestable MARKets AND THE Theory of Industry STRUCTURE (1982)) (using various assumptions in an analysis of the theory of contestable markets). This does not deny that simplifying assumptions can be useful to analysis, but assumptions can, and often do, drive conclusions. See, e.g., Ernest Nagel, Assumptions in Economic Theory, 53 AM. ECON. REV. 211 (1963).

141. See John M. Golden, "Patent Trolls" and Patent Remedies, 85 Tex. L. REV. 2111, 2118-24 (2007) (providing historical context for the difficulty of determining costs and benefits of patent policy). 
In the absence of robust data, policy analysis should be rooted in basic precepts of support for private property rights and voluntary exchanges-precepts that, where they have been the basis for law and policy, have fairly consistently been associated with economic success. ${ }^{142}$ Firms that have an interest in reducing litigation risks to their own operations commonly are open to negotiating agreements with others that reciprocally reduce the threat of patent litigation to them..$^{143}$ These mutually acceptable agreements, like voluntary exchanges in general, can be expected to be beneficial to the parties and, except in extreme cases where they implement efforts to reduce competition, to be socially beneficial as well. ${ }^{144}$ These arrangements, which are seen among competing smartphone producers (even those that have engaged in patent contests), ${ }^{145}$ do not completely solve problems associated with the current smartphone wars, but they generally constitute steps in the right direction.

\section{Non-PRACTICING ENTITIES (NPES)}

The transaction cost and, especially, hold-up problems with patent thickets, however, are less easily resolved when the

142. See, e.g., Robert J. BARRo, Determinants of ECONOMIC GROWTH: A CROss-CoUNTRY EMPIRICAL STUDY (MIT Press 1997) (examining the general relationship between property rights and economic success and more complicated relationship to economic growth rates); MILTON FRIEDMAN, CAPITALISM AND FreEDOM (Univ. of Chi. Press 1962) (discussing economic success and personal freedom); Enrico Colombatto, Are Property Rights Relevant for Development Economics? On the Dangers of Western Constructivism, in THE Elgar COMPANION TO THE ECONOMICS OF PROPERTY RIGHTS 251-69 (Enrico Colombatto ed., 2004). A fairly good approximation of the correlation between property rights and economic success can be seen by comparing the rankings in TERRY MILLER ET AL., 2013 INDEX OF ECONOMIC FreEdom: Promoting ECONOMIC FreEdom AND PROSPERITY (Heritage Found. 2013), available at http://www.heritage.org/index/pdf/2013/book/index _2013.pdf, with national rankings by per capita GDP in GDP Per Capita (Current US\$), WORLD BANK, http://data.worldbank.org/indicator /NY.GDP.PCAP.CD?order=wbapi_data_value_2011+wbapi_data_value+wbapi _data_value-last\&sort=asc (last visited Oct. 12, 2014) (noting that correlation is especially pronounced if adjusted for effects of large oil reserves in nations with relatively unstable governments).

143. See, e.g., Ian Sherr, Apple, HTC Settle Patent Dispute, Sign Licensing Pact, WALL ST. J. (Nov. 11, 2012, 3:52 PM), http://online.wsj.com /news/articles/SB10001424127887324894104578111792346747174 (describing the licensing deal Apple and HTC signed in order to end litigation).

144. Klein, supra note 128 , at 3-4.

145. See, e.g., Sherr, supra note 143. 
enterprises involved have sharply divergent interests. ${ }^{146}$ Buildand-let-build accords work only if both parties have equivalent interest in building. ${ }^{147}$ The Federal Trade Commission singled out entities that do not use patents to make products themselves-commonly called non-practicing entities (NPEs)for special criticism as contributing to excessive litigation. ${ }^{148}$ Additionally, four Justices, concurring in the Supreme Court's eBay decision, cautioned that firms that "use patents not as a basis for producing and selling goods but, instead, primarily for obtaining licensing fees" will be less likely to satisfy the requirements for injunctive relief when they assert patent rights. ${ }^{149}$

Since that time, courts addressing complaints from NPEs frequently have referred to a plaintiff's non-practicing status in assessing the propriety of injunctive relief and have denied injunctions for patent infringement in a substantial proportion of cases. ${ }^{150}$ A growing chorus of commentary has advocated going further, proposing that courts deny or sharply curtail injunctions to NPEs. ${ }^{151}$ Commentators have observed that the number and cost of NPE suits is rising. ${ }^{152}$ Two scholars put a figure of $\$ 29$ billion on the direct cost of NPE suits in 2011,153

146. See Sannu K. Shrestha, Trolls or Market Makers? An Empirical Analysis of Nonpracticing Entities, 110 COLUM. L. REV. 114, 125 (2010).

147. Id.

148. Fed. Trade Comm'n, To Promote Innovation: The Proper BALANCE OF COMPETITION AND PATENT LAW AND POLICY 31-32 (2003), available at http://www.ftc.gov/os/2003/10/innovationrpt.pdf (discussing the characteristics of NPEs).

149. eBay Inc. v. MercExchange, L.L.C., 547 U.S. 388, 395-97 (2006) (Kennedy, Stevens, Souter \& Breyer, J.J., concurring); FED. TRADE COMM’N, supra note 148 , at $31-32,38-43$.

150. E.g., Benjamin N. Simler \& Scott McClelland, A Model for Predicting Permanent Injunctions After eBay v. MercExchange, 5 BLOOMBERG L. REP.INTELL. PROP., no. 15, 2011 ("[T] he percentage of cases in which an injunction is entered is in stark contrast to pre-Ebay statistics ....").

151. E.g., Colleen V. Chien, From Arms Race to Marketplace: The Complex Patent Ecosystem and Its Implications for the Patent System, 62 HASTINGS L.J. 297 (2010); James R. Farrand, Territoriality and Incentives Under the Patent Laws: Overreaching Harms U.S. Economic and Technological Interests, 21 BERKELEY TECH. L.J. 1215 (2006); Gerard N. Magliocca, Blackberries and Barnyards: Patent Trolls and the Perils of Innovation, 82 NOTRE DAME L. REV. 1809 (2007); Bruce Sewell, Troll Call, WALL ST. J., Mar. 6, 2006, at A14.

152. See infra notes 153-54.

153. See, e.g., James Bessen \& Michael J. Meurer, The Direct Costs from NPE Disputes, 99 CORNELL L. REV. 387, 388-91 (arguing that patent litigation costs associated with NPEs are larger than many observers believe and that 
and some studies have found the proportion of NPE suits climbing sharply in recent years. ${ }^{154}$

However, increasing costs and growing numbers of suits are the general case for U.S. patent holders (NPE or not), as one would expect in a world where innovation increasingly drives large segments of the economy. ${ }^{155}$ Patent litigation is costly, both to the plaintiff and to the defendant, regardless of the identity of the plaintiff. ${ }^{156}$ Look at the suits involving Apple and Samsung, for example; these two non-NPE litigants have doubtless spent far more on litigation than any NPE. 157 Moreover, the common assumption of the relative willingness of NPEs to litigate is not necessarily evidence of strategic behavior. It may instead reflect asymmetries in the efficiency of NPEs versus other entities at litigating (due to organizational issues, scope of an enterprise's work, or other factors) or in the nature of relationships between the patent holder and the

these are largely social losses, not transfers among firms); see also EXEC. OFFICE OF THE PRESIDENT, PATENT ASSERTION AND U.S. INNOVATION 5 (2013), available at http://www.whitehouse.gov/sites/default/files/docs/patent_report .pdf (describing the increasing prevalence of "PAE suits, and patent suits in general, in recent years"). But see David L. Schwartz \& Jay P. Kesan, Analyzing the Role of Non-Practicing Entities in the Patent System, 99 CORNELL L. REV. 425 (2014) (arguing that the NPE litigation cost number arrived at by Bessen \& Meurer is unreasonably high and at best states the upper bound of possibilities).

154. Sara Jeruss et al., The America Invents Act 500: Effects of Patent Monetization Entities on US Litigation, 11 DUKE L. \& TECH. REV. 357, 361 (2012).

155. See, e.g., John R. Allison et al., Patent Litigation and the Internet, STAN. TECH. L. REV., 2012, at 1, 1 n.2 (highlighting changes from 2001 to 2009); Alan Marco et al., Do Economic Downturns Dampen Patent Litigation? 2-4 (5th Annual Conference on Emprical Legal Studies Paper, 2010), available at http://papers.ssrn.com/sol3/papers.cfm?abstract_id=1641425 (reviewing growth in patent litigation in connection with divergent effects of different types of economic downturns on patent litigation); Jim Kerstetter, How Much Is That Patent Lawsuit Going to Cost You?, CNET (Apr. 5, 2012, 10:00 AM), http://news.cnet.com/8301-32973_3-57409792-296/how-much-is-th at-patent-lawsuit-going-to-cost-you/ (reporting results of a survey by the American Intellectual Property Law Association).

156. See Allison et al., supra note 155. This does not mean that costs for patent litigation are symmetrical for plaintiffs and defendants, especially costs associated with discovery, or that costs have increased proportionately for both plaintiffs and defendants across all classes of plaintiff and all types of patents.

157. E.g., Duhigg \& Lohr, supra note 101. 
putative infringer. ${ }^{158}$ The possible efficiency explanations for NPE litigation do not necessarily prove that NPEs are equally good candidates for strong patent protections as other patentees (from a social welfare perspective), but something more than has been offered thus far is needed to make the case that curtailing injunctions for NPEs as a class is beneficial. ${ }^{159}$

Certainly, critics of NPE litigation are right that NPEs are less likely to engage in quid pro quo cross-licensing or similar arrangements that do not involve straightforward payment of royalties as an alternative to patent infringement litigation. ${ }^{160}$ The absence of that alternative will affect some of the costs associated with patent litigation and, ultimately, with use of products and processes that are or might be covered by patents. ${ }^{161}$ But the notion that the enforcement of patents held by NPEs is especially costly, or that NPE suits generally should be viewed with suspicion, is easily overstated. ${ }^{162}$

NPEs include universities and similar research facilities, independent inventors and small businesses, companies that are changing business focus from one sector to another, and firms that principally operate as purchasers and enforcers of patent rights. ${ }^{163}$ Universities are better suited to research than to turning ideas into products and selling them in commercial

158. See, e.g., Vincenzo Denicolò et al., Revisiting Injunctive Relief: Interpreting eBay in High-tech Industries with Non-Practicing Patent Holders, 4 J. COMPETITION L. \& ECON. 571, 585-89 (2008) (describing "NonManufacturing, Non-Competing Patent Holders"); Golden, supra note 141, at 2132 (discussing information asymmetries in patent litigation); Kieff, supra note 29; Ronald J. Mann, Do Patents Facilitate Financing in the Software Industry?, 83 TEX. L. REV. 961, 1005 (2005) (explaining that IBM's "relative lenience" may be attributed to "asymmetric risks"); Shrestha, supra note 146, at 129 ("NPEs are well positioned to solve this informational asymmetry ....").

159. See Denicolò et al., supra note 158 , at 576-77 (warning that creating too strong of rules for granting injunctive relief in relation to NPEs has the possibility of "undercompensating innovation").

160. FED. TRADE COMM'N, supra note 148, at 31 (suggesting that an "NPEs' invulnerability may create a competitive problem if it prevents the type of cross-licensing that has evolved as a 'safety valve"').

161. Id. at 30-33 (discussing the potential costs associated with NPEs and patent amassing strategies).

162. See Denicolò et al., supra note 158 , at 576 .

163. See, e.g., Shrestha, supra note 146, at 117 n.16. Special considerations respecting this last group of NPEs are addressed in the section immediately following. See infra Part III.E. 
markets. ${ }^{164}$ So are many other NPEs, such as small businesses that generate innovations that are more efficiently commercialized by others that have established production facilities and marketing networks. 165

Denying all of these NPEs remedies that are generally available to patent holders simply because they are less apt to engage in cross-licensing or patent pooling arrangements diminishes the likely value of NPEs' patents. 166 Exclusive rights to control patented items are rarely enforced as effectively with only a damages remedy instead of the full panoply of rights. ${ }^{167}$ That should be obvious: if damages were as useful in all cases as injunctive relief, there would be no reason for plaintiffs to ask for injunctive relief and no reason for potential defendants to be concerned about that remedy. The inducement to innovate that patent rights represent, hence, is not as strong if NPEs do not enjoy rights to injunctive as well as damages relief. 168

Even if costs associated with injunctive relief are greater in suits by NPEs as a class than in other patent suits (an open question), more critical questions remain: (1) what are the relative magnitudes likely to be for those costs and for costs entailed in limiting relief; and (2) do the most cost-effective limitations on relief apply across that class or in a subset of NPE suits? The real problems firms risking accusations of patent infringement face with transaction costs and hold-ups have already been noted. ${ }^{169}$ The costs associated with the risk of hold-up and with transacting around patent rights issues, however, are not likely to be the same for all NPEs or all patents. ${ }^{170}$ Enforcement of a patent on a major innovation pioneered by a university research facility, for example, would not pose the same hold-up and transaction cost issues as those associated with a firm intent on extracting the maximum

164. See Shrestha, supra note 146, at 127 (discussing how certain NPE entities "lack the necessary resources to develop and market a product").

165. Id.

166. See FED. TRADE COMM'N, supra note 148, at ch. 2, 31-32.

167. See, e.g., Denicolò et al., supra note 158, at 577-83 (describing the benefits of injunctive relief); Shrestha, supra note 146, at 134 ("Without the threat of an injunction, smaller entities may not be able to bargain for fair licensing fees.").

168. See Denicolò et al., supra note 158 , at 574-76.

169. See Shrestha, supra note 146, at 124 .

170. See id. 
revenue by strategic assertion of rights to patents covering small advances in functions used as a minor input to numerous, complex products. ${ }^{171}$ The university-generated major patent would be more likely than the comparison patent to be known in advance of the potentially infringing conduct, less likely to be used strategically to extract money from possible infringers, and new constraints on enforcement of such patents would be more apt to impinge on significant investments associated with innovation. ${ }^{172}$ What does that suggest for policy and for legal rules? This Part continues to examine potential distinctions among types of plaintiffs; distinctions among types of patent claims are addressed in Part IV.

\section{E. Patent Assertion Entities (PAEs)}

Recognizing that all NPEs are not the same, critics of overly aggressive patent enforcement have recently narrowed their focus to a subset of NPEs, firms labeled patent assertion entities (PAEs).173 These are the firms that purchase patent rights primarily for the purpose of extracting payments from enterprises that use the patented products or processes to produce goods. ${ }^{174}$ This is the category of enterprise that generally attracts the label of "patent troll" (or worse). ${ }^{175}$ The poster child for bad results from suits by PAEs is the NTP-RIM (now BlackBerry) case. The short version of the story is this:

NTP sued RIM for patent infringement, won in federal district court, and obtained an injunction that would have shuttered Blackberry service in the United States. Although the injunction was suspended during negotiations between the litigants, the judge made clear that he was not going to deny injunctive relief just to avoid the problems that it would cause Blackberry users. NTP won a huge settlement (almost twenty times the amount the judge fixed as the reasonable value of royalties for the infringed patents), even as its patents were

171. See id. at $140-44$.

172. This may also explain, in part at least, the findings of a study showing that NPE-asserted patents tended to be of higher value than other patents as measured by citations in scientific literature. See id.

173. E.g., EXEC. OfFICE OF THE PRESIDENT, supra note 153; Jeruss et al., supra note 154, at 367-72. Although the increased attention to these entities is relatively recent, the term dates back at least to the FTC's 2003 report. FED. TRADE COMM'N, supra note 148, at 31 (referring to "patent assertion firms").

174. Jeruss et al., supra note 154 , at 367.

175. See, e.g., Sewell, supra note 151; Wu, supra note 18. 
being reviewed and rejected as invalid by examiners in the U.S.

Patent and Trademark Office. ${ }^{176}$

The difference between the value assessed by the judge and the settlement RIM reached with NTP plainly reflects the value RIM placed on avoiding a shutdown of its service. ${ }^{177}$ That, in essence, is the difference between the availability of an injunctive remedy as opposed to a damages remedy. Damages can be insufficient to provide protection to rights holders if courts set the number lower than the value the rights holder places on allowing use of the patented item or process, or damages can be excessive (witness the Apple-Samsung verdict). ${ }^{178}$ In this instance, however, the reason the settlement figure greatly exceeded the court's assessment of value probably was not that NTP viewed the innovation as having more economic worth than RIM or the court (a common barrier to negotiating agreements in many settings). ${ }^{179}$ Instead, the much higher settlement amount reflected NTP's ability to leverage the threat of shuttering RIM's BlackBerry service, with attendant losses of not only immediate use but future use as well. ${ }^{180}$

While the extra return to the patent holder as a result of the threatened injunction was widely noted, observers were even more struck by the fact that NTP was free to push for the shutdown of BlackBerry service because it had nothing to lose in relations with RIM. ${ }^{181}$ Some NPEs, such as universities or other research facilities, may have reasons to seek accommodations with patent infringers broadly similar to motivations for business enterprises that use one another's patented innovations. ${ }^{182}$ Universities, for example, may receive

176. CASs \& HYLTON, supra note 31, at 162 (footnotes omitted).

177. E.g., id.; Wu, supra note 18.

178. See Shrestha, supra note 146, at 134 ("[D]amages . . are notoriously difficult to calculate and may well undercompensate the patent owner.") (footnotes omitted); Lowensohn, supra note 1.

179. See CASS \& HYLTON, supra note 31 , at 162.

180. Wu, supra note 18.

181. See, e.g., Chien, supra note 151, at 318; Lemley \& Shapiro, supra note 119, at 2009; Sewell, supra note 151 (noting that NTP does not make a competitive product nor is it "even in the business of making products"); Wu, supra note 18 (explaining that NTP has no products or employees).

182. See generally Mark A. Lemley, Are Universities Patent Trolls?, 18 Fordham InTELl. Prop. MEDiA \& ENT. L.J. 611, 615 (2008) (describing universities as NPEs, noting that "their incentives in dealing with the patent 
(or seek) philanthropic gifts from potential targets of patent enforcement or from individuals (alumni most often) associated with those enterprises. ${ }^{183}$ Educational and research institutions also might value freedom from limitations on their use of various patent-protected inputs in pursuit of their own teaching and research functions, giving these entities another incentive to reach reciprocal licensing arrangements. ${ }^{184}$ These interests will not necessarily produce the same level of willingness to reach agreement on cross-licensing or similar means for reducing prospects for litigation-and particularly for enforcement of rights through remedies that are especially costly to the targets of litigation-as would be expected for many commercial enterprises. ${ }^{185} \mathrm{NPE}$ interests of this sort should, however, moderate risks associated with enforcement of patent rights in settings such as the NTP-RIM case. ${ }^{186}$

PAEs, in contrast, seem wholly free from similar constraints. Their principal focus is on patent enforcement, and their own economic success correlates positively and directly with the magnitude of the sums they can extract through litigation or threat of litigation. ${ }^{187}$ As a rule, PAEs do not have any apparent incentive to limit the claims they make or to refrain from the most aggressive enforcement of patent rights. ${ }^{188}$ Aggressive enforcement that imposes asymmetrically high costs on defendants may be especially useful to PAEs. ${ }^{189}$

system align in many ways with those of private-sector patent licensing shops").

183. See, e.g., id. at 616-17 ("Second, the companies with which [universities] are negotiating often want exclusivity. They are especially likely to get it if the company in question is a faculty-organized startup.").

184. E.g., Chien, supra note 151, at 327-28 ("Research and development entities, for example, use patent license fees to fund technology development ....").

185. See generally id. at 328 ("However, with their large patent portfolios, R\&D entities are well poised to shift their emphasis to enforcement.").

186. See, e.g., Lemley, supra note 182, at 629 ("One of the differences between universities and private licensing shops is that universities are, by and large, not engaged in hiding the ball, waiting until people have developed an industry and then popping up and demanding a disproportionate share of royalties based on irreversible investments.").

187. See EXEC. OfFICE OF THE PRESIDENT, supra note 153, at 1.

188. Id. at 1, 6; Fed. Trade Comm'n, The Evolving IP MarketPlace: Aligning Patent Notice And Remedies with Competition ch. 2, ch. 8 (2011).

189. E.g., Abusive Patent Litigation: The Impact on American Innovation and Jobs, and Potential Solutions: Hearing Before the H.R. Subcomm. on 
These observations have supported calls for limitation of injunctive relief to PAEs to prevent the sort of result reached in the NTP-RIM litigation. ${ }^{190}$

The question for policymakers is whether the relative freedom for PAEs to push for patent enforcement in ways that might produce excessively large payments or undue disruption to functions of firms using patented technologies, components, or methods of operation, justifies special restrictions on PAEs or on the relief available to them. ${ }^{191}$ That is not an easy question. It cannot be answered simply by pointing to specific examples where PAEs were overcompensated for the value of the patent rights asserted or where patent assertions disrupted legitimate commercial operations-those examples can point toward potential answers if they are typical of a broader class of cases where PAE litigation results in net social costs, but they will not likely be the entire story.

The question requires balancing the costs of excessive enforcement against the costs of under-enforcement. ${ }^{192}$ Neither is readily pinned down. ${ }^{193}$ PAEs necessarily should be expected to be more efficient enforcers of patent rights than those whose rights they acquire; and they also can serve useful arbitrage, funding, and research-promotion functions. ${ }^{194}$ If patent rights would be under-enforced without the operation of PAEs, and especially to the extent that under-enforcement in this context would reduce efficient research incentives, efforts to cut back on PAE remedies would reduce social welfare. ${ }^{195}$ The costs of patent litigation are often cited as evidence that patent litigation imposes excessive burdens on firms seeking to use patented products and processes (potential defendants in

Courts, Intellectual Prop. \& the Internet of the H. Comm. on the Judiciary, 113th Cong. 1 (2013) (statement of John Boswell); EXEC. OFFICE OF THE PRESIDENT, supra note 153, at 6-7.

190. E.g., FED. TRADE COMM'N, supra note 188, at ch. 8; Chien, supra note 151 , at 310 .

191. See FED. TRADE COMM'N, supra note 188, at 220-21.

192. See infra notes 193-200.

193. See Golden, supra note 141, at 2118 (arguing that "a simplistic view of patents' benefits and costs cannot be correct").

194. E.g., Denicolò et al., supra note 158, at 575; Golden, supra note 141, at 2117; Shrestha, supra note 146, at 130-31.

195. See Golden, supra note 141, at 2117 (arguing that "a categorically discriminatory market for patent rights may slow, rather than promote, progress"). 
patent litigation), but these costs also could deter desirable patent enforcement actions.196 They also can discourage at least some undesirable patent suits.197 In other words, litigation costs are likely to have complex effects on public welfare, some good, some bad; the real issues have to do with what the costs represent and how they affect behavior. ${ }^{198}$ If litigation costs discourage "frivolous" litigation, fine; if litigation imposes asymmetric costs that allow PAEs to extract excessive settlements from productive firms that practice methods or use components that might infringe patent rights, these costs have a very different social impact.

Even PAE enforcement activity that produces costs in excess of merited returns for the value of patents in the individual case, as certainly appears to have happened in the NTP-RIM example, could simply balance under-enforcement elsewhere in the patent system-perhaps not even fully offsetting under-enforcement. While enterprises that want to use technologies arguably subject to patent protection do face high transaction costs in settings like the mobile device market, the patent owners frequently face correlatively high transaction costs in identifying infringing uses of their technologies and resolving disputes over them. ${ }^{199}$ These costs very likely will be particularly discouraging to many of the types of enterprise found among NPEs, such as independent

196. See, e.g., BESSEN \& MEURER, supra note 11, at 120-32.

197. Of course, the lower the bar is set to filing suit and the more quickly costs can be shifted to defendants, the less likely this effect is to be significant. E.g., Louis Kaplow, Private Versus Social Costs in Bringing Suit, 15 J. LEGAL STUD. 371, 376 n.9 (1986); Peter S. Menell, A Note on Private Versus Social Incentives to Sue in a Costly Legal System, 12 J. LEGAL STUD. 41, 43 (1983).

198. See, e.g., Kaplow supra note 197, at 385.

199. Costs of identifying infringements and resolving disputes are distinct from costs of filing suit. Where the former costs are high, there also is additional incentive to use alternatives, such as scatter-shot letters asserting potential infringement, without factual investigation to support the accusation. E.g., William J. Francis, Lodsys Targets App Developers Over Infringement Claims, TECHREPUBLIC (Aug. 25, 2011, 6:10 AM), http://www.techrepublic.com/blog/software-engineer/lodsys-targets-app-devel opers-over-patent-infringement-claims/. The almost exclusive use of this technique by PAEs, however, suggests that factors other than the cost of determining the identity of actual infringers are significant. E.g., Joe Mullin, Wi-Fi Patent Troll Hit with Racketeering Suit Emerges Unscathed, ARS TECHNICA (Feb. 13, 2013, 9:05 AM), http://arstechnica.com/tech-policy /2013/02/wi-fi-patent-troll-hit-with-novel-anti-racketeering-charges-emerges-u nscathed/. 
inventors, small businesses, and academic researchers. In this context, there is a significant risk of under-enforcement in parts of the system aside from the activities of PAEs. 200

Another element critical to evaluation of the functioning of the current system of patent rights enforcement, and ultimately to disposition of the controversy about PAE enforcement rights, is the error rate and distribution-the degree to which litigation produces erroneous decisions and the types of errors produced.201 As scholarship on the economics of litigation makes clear, lawsuit activity cannot be evaluated without attention to the frequency and nature of the errors made in sorting through legal claims and also the impact those errors have on the activities that lie behind the suits. ${ }^{202}$

If the legal system works well, courts will sort through the suits, dismiss those that are baseless relatively quickly, and dispose of the remaining suits in line with the merits; investment in litigation by both sides generally will be scaled in response to perceptions of a suit's merit (lower spending on suits that are less apt to succeed), and the efficiency and accuracy of systems that work well will tend to induce both investment in litigation and in background activities that reflect social value. ${ }^{203}$ If, however, a class of suits includes

200. E.g., Denicolò et al., supra note 158, at 583; Golden, supra note 141, at 2118. Findings of dramatic increases in PAE litigation relative to other suits are not complete theoretical responses to hypotheses of underenforcement by non-PAE patent owners, but they at least suggest that something else may be at play. See infra Part IV.

201. See generally Keith N. Hylton, Costly Litigation and Legal Error Under Negligence, 6 J.L. ECON. \& ORG. 433, 446-51 (1990) (examining the effect of error rate "on incentives to litigate").

202. E.g., Robert D. Cooter \& Daniel L. Rubinfeld, Economic Analysis of Legal Disputes and Their Resolution, 27 J. ECON. LITERATURE 1067, 1088 (1989); Hylton, supra note 201, at 446; William M. Landes \& Richard A. Posner, Adjudication as a Private Good, 8 J. LEGAL STUD. 235, 252 (1979); Steven Shavell, The Fundamental Divergence Between the Private and the Social Motive to Use the Legal System, 26 J. LEGAL STUD. 575, 575 (1997); Steven Shavell, The Level of Litigation: Private Versus Social Optimality of Suit and Settlement, 19 INT'L REV. L. \& ECON. 99, 99 (1999).

203. E.g., Hylton, supra note 201, at 446-47; Avery Katz, Judicial Decisionmaking and Litigation Expenditure, 8 INT'L REV. L. \& ECON. 127, 139 (1988); Landes \& Posner, supra note 202, at 273; George L. Priest \& Benjamin Klein, The Selection of Disputes for Litigation, 13 J. LEGAL STUD. 1, 55, 13-14 (1984). Of course, with any level of error, there will remain a divergence between social value and private investment in litigation activity. See The Fundamental Divergence Between the Private and the Social Motive to Use the Legal System, supra note 202. 
many that are particularly likely to be baseless and also are more likely than typical suits to be decided incorrectly, they will generate direct social welfare costs and create incentives for social-welfare-reducing settlements or other socially wasteful litigation-avoidance measures. ${ }^{204}$ Costs also would be higher, given any error rate for the relevant category of judicial decisions, if a particular class of litigants has asymmetric information (for example, on the actual novelty of a claim) and behaves strategically (such as in the NTP-RIM case). ${ }^{205}$

On most margins, litigation by PAEs should resemble litigation by other patentees, facing the same legal rules and procedures for assessing patent validity, infringement, and value. Thus, there is no reason to expect that errors for judicial disposition of cases brought by PAEs are higher than for other patent cases or that PAEs generally behave in ways distinguishable from other patent litigants in their decisions respecting the litigation. For example, PAEs should be just as motivated to scale their litigation expenditures to the likelihood of success as other litigants. Further, there is no obvious reason to expect that PAEs have stronger informational asymmetries than other patent holders; they are not obviously in a better position vis-à-vis defendants in patent litigation to assess the merits of patent claims (and certainly are not specially advantaged in this respect as compared to other patent holders). ${ }^{206}$ If PAEs are merely more efficient enforcers of legitimate patent rights, PAEs should not impose special social costs through litigation.

204. E.g., Avery Katz, The Effect of Frivolous Lawsuits on the Settlement of Litigation, 10 INT'L REV. L. \& ECON. 3, 24-25 (1990).

205. E.g., Keith N. Hylton, The Economics of Third-Party Financed Litigation 22 (Boston Univ. Sch. of Law, Working Paper No. 11-57, 2011). Recognizing the existence of asymmetric information in such settings is not enough to prevent the ensuing social costs, as the party with less information can estimate the direction in which to adjust from any offer or claim by the party with more information, but cannot know the right magnitude of adjustment in any given case. See, e.g., George A. Akerlof, The Market for "Lemons": Quality Uncertainty and the Market Mechanism, 84 Q.J. ECON. 488, 489 (1970).

206. See generally Schwartz \& Kesan, supra note 153, at 451 ("But there is also empirical evidence that the patents asserted by NPEs are similar to patents asserted by practicing entities. There is some evidence that the most litigious NPEs lose more often when the cases are taken to a final judgment ....”). 
There is, however, one margin that could remain different for PAEs and others. For the same reason that PAEs will not be as willing as other patent holders to resolve suits through mechanisms such as cross-licensing or to make other accommodations, it is plausible that PAEs as a class would behave strategically in litigation in ways that other patent holders would not, or at least would behave strategically more often than other patent plaintiffs. ${ }^{207}$ PAEs may, for example, assert weaker claims in hopes of extracting a settlement, where other patent holders would be more sensitive to the imposition on parties with whom they might hope to have future cooperative dealings and more concerned with the damage to relationships that would occur if opposing parties came to believe that the patent assertion was less than straightforward. ${ }^{208}$ Given any level of error in the system, this would correlate with higher social costs from PAE suits than from other patent suits. 209

This is logical given the information available on the potential for hold-up in some circumstances, but it does not provide a basis for bold changes to the law, such as restricting PAE suits. The evidence respecting costs of NPE suits (a category that encompasses PAE suits), as already noted, in itself does not show that such suits are socially undesirable as a class. ${ }^{210}$ The factors that would make PAE suits especially likely to be undesirable-if the patents asserted tend to be weak and if errors in adjudication are high-are matters that increasingly are subjects of commentary, but not subjects that have elicited the sort of information that all sides to the debate

207. See, e.g., Colleen V. Chien, Assistant Professor, Santa Clara Univ. Sch. of Law, Presentation at the FTC/DOJ Hearing on PAEs: Patent Assertion Entities (Dec. 10, 2012), available at http://papers.ssrn.com/sol3/papers.cfm ?abstract_id=2187314.

208. This is consistent with the findings of increasing PAE litigation relative to other patent claimants as well as to the relative frequency of PAE assertion of software patents. See, e.g., Chien, supra note 207; Jeruss et al. supra note 154, at 362-64; Robin Feldman et al., The AIA 500 Expanded: The Effects of Patent Monetization Entities (Univ. Cal. Hastings, Working Paper No. 45, 2013), available at http://papers.ssrn.com/sol3/papers.cfm?abstract id $=2247195$. Although the precise figures for PAE litigation can be disputed, as they turn on particular definitions for that category as well as on the data source for patent litigation information, the general proposition respecting increasing importance of PAE litigation seems clearly established.

209. E.g., Katz, supra note 204, at 25-27.

210. See Hylton, supra note 205, at 22. 
can agree on as a common factual predicate. ${ }^{211}$ In the absence of clear data on these issues, the system probably is best left to function as it does at present at least on most margins, by providing remedies to all patent owners, including PAEs, but with a higher degree of skepticism (possibly a significantly higher degree) regarding PAE demands for injunctive relief. ${ }^{212}$ The appropriate degree of skepticism in any given instance would increase if other factors are present suggesting that the costs of relief in that instance would be heightened, as it would where the type of claim asserted is associated with weaker patent quality or higher error rates. ${ }^{213}$ Those are matters addressed below.

\section{SOFTWARE: PATENTLY PROBLEMATIC?}

Two factors highlighted in Part III, the roles of patent quality and error rates, merit special attention in sorting through the stresses in the patent system illustrated by the smartphone wars. While lower patent quality and higher error rates raise the cost of patent litigation, the critical question is how to identify cases that are likely to embody these characteristics. Notably, both characteristics are associated with one particular class of patents, commonly referred to as software patents. ${ }^{214}$

"Software" is the term generally given to instructions embodied in code designed to make machines such as computers (but increasingly also a range of other machines, including smartphones) work. 215 The term initially was coined to distinguish intangible machine instructions from tangible

211. See Schwartz \& Kesan, supra note 153, at 427, 429, 451 ("There is little firm empirical evidence supporting this scenario of the combination of dubious patent assertions and low settlement demands.").

212. This does not mean that changes on other margins might not improve the system overall or that such changes might not have special pay-off in respect of PAE suits, especially so far as those suits are characterized by assertion of weaker patents and imposition of higher litigation costs due to reluctance towards settlement or a strategic commitment to use asymmetric litigation costs as a form of leverage. See supra text accompanying notes 18790.

213. See infra Part IV.

214. See infra Part IV.D.

215. See, e.g., Eric Goldman, Fixing Software Patents 5 (Santa Clara Univ. Sch. of Law, Working Paper No. 01-13, 2013), available at http://digitalcommons.law.scu.edu/facpubs/596/. 
machines, although the instructions are embodied in tangible forms and are critical in directing the operation of machines. ${ }^{216}$ This makes software a bit different from most results of intellectual endeavor that fit easily in one category of intellectual property law or another. The base question respecting software's relationship to intellectual property law was whether it qualified for patent protection (as an innovation applicable to the utilitarian functioning of useful products) or for copyright protection (as a literary work, because it constituted a unique expression that was fixed in a specific medium). ${ }^{217}$

\section{A. SOFTWARE IN PATENT AND COPYRIGHT LAW: FIRST LOOKS}

Initially, courts and administrators looking at the issue concluded that software did not qualify for protection under patent law but did under copyright. ${ }^{218}$ Following a long line of decisions that rejected patents for "abstract ideas," "scientific principles," or "principles of nature,"219 the Supreme Court in the 1970s invalidated software patents that expansively covered uses of a mathematical formula or numerical algorithm - claims framed broadly enough (in the Court's view) to preempt too large a field of potential uses. ${ }^{220}$ In Gottschalk $v$. Benson, ${ }^{221}$ the Court held that an algorithm for converting binary-coded numbers into binary numbers could not be patented, a conclusion commentators viewed as tantamount to a holding that computer software was not patentable. ${ }^{222}$ The Court reaffirmed the Benson holding in Parker v. Flook,223 finding that the creation of software for controlling aspects of

216. See, e.g., Mark A. Lemley, Software Patents and the Return of Functional Claiming, 2013 WIS. L. REV. 905, 927-28 n.89 (2013).

217. See, e.g., Gottschalk v. Benson, 409 U.S. 63, 71-72 (1972).

218. See id.

219. E.g., O'Reilly v. Morse, 56 U.S. 62, 112-13 (1853); CASS \& HYLTON, supra note 31; ROBERT PATRICK MERGES \& JOHN FITZGERALD DUFFY, PATENT LAW AND POLICY: CASES AND MATERIALS 164-85 (5th ed. 2011); Arti Kaur Rai, Regulating Scientific Research: Intellectual Property Rights and the Norms of Science, 94 NW. U. L. REV. 77, 77-80 (1999).

220. See, e.g., Parker v. Flook, 437 U.S. 584, 590 (1978); Gottschalk, 409 U.S. at $71-72$.

221. Gottschalk, 409 U.S. at 71-72.

222. See Donald S. Chisum, The Patentability of Algorithms, 47 U. PITT. L. REV. 959, 1020 (1986).

223. Parker, 437 U.S. at 590. 
catalytic conversion did not yield a patentable "process" within the meaning of the Patent Act because there was insufficient inventiveness apart from the mathematical formula embodied in the process. ${ }^{224}$ In the early 1980 s, the Court's decision in Diamond $v$. Diehr, that reliance on a mathematical equation as part of a novel process tied to a well-specified and sufficiently narrow practical application would not invalidate a patent, 225 showed the limits of Benson and Flook and opened the door to software patents. That remained the state of play until the Court returned to the field over the past decade to reassert its concerns with expansive preemption of uses of mathematical concepts. ${ }^{226}$

While courts were skeptical of software's fit with patent law until the 1980s (and have retained at least a portion of that skepticism), the administering authorities were disposed to find software a home within the rubric of copyright.227 From 1964 on, software programs received protection from the Copyright Office, which conferred copyright recognition under the "rule of doubt" (reserving the question of legality for the courts, but inclining toward registration of arguably copyrightable material). ${ }^{228}$ The doubt expressed in this treatment, however, was also reflected in debates over the proper treatment of software programs during debates over revision of the copyright law in the early 1970s. ${ }^{229}$ In 1974, Congress created the National Commission on New Technological Uses of Copyrighted Works (CONTU) to consider what protection was appropriate for software, among other things. ${ }^{230}$ The general revision and reenactment of copyright law, passed and signed into law in 1976, seemed to contemplate

224. Id. at 594 .

225. See Diamond v. Diehr, 450 U.S. 175, 175-76 (1981); see also Mackay Radio \& Tel. Co. v. Radio Corp. of Am., 306 U.S. 86, 94 (1939) ("While a scientific truth, or the mathematical expression of it, is not patentable invention, a novel and useful structure created with the aid of knowledge of scientific truth may be.").

226. E.g., Mayo Collaborative Servs. v. Prometheus Labs., Inc., 132 S. Ct. 1289, 1294 (2012); Bilski v. Kappos, 561 U.S. 593 (2010).

227. See infra notes 228-37 and accompanying text.

228. See Robert A. GORMAN ET AL., COPYRIGHT: CASES AND MATERIALS 184 (8th ed. 2011).

229. Id.

230. Act of Dec. 31, 1974, Pub. L. No. 93-573, 88 Stat. 1873 (creating CONTU). 
continued coverage for software under the copyright rubric, ${ }^{231}$ but Congress also plainly had reserved the possibility of revising the law to alter that rule or to strengthen it, depending on CONTU's findings. ${ }^{232}$ CONTU concluded that other forms of intellectual property protection might also be appropriate in particular circumstances, but that the most comfortable fit for the creative elements embedded in software programs was protection under copyright law.233 CONTU recommended, and Congress enacted, modest changes to the copyright law to embrace coverage of computer software programs. ${ }^{234}$

CONTU's report embraced copyright protection for a broad sweep of software programs, including those embodied in media readable only by machines rather than directly by humans. ${ }^{235}$ That recommendation continued to be controversial, however, and doubt about the correctness of that conclusion as a matter of law was the basis for a preliminary ruling by the district court in Apple Computer, Inc. v. Franklin Computer Corp. ${ }^{236}$ The Third Circuit's reversal of the district court read the law as definitively resolving the matter, opening copyright for "literary works" to those writings that are preserved in forms readable by machines and intended to instruct the machines' operations, rather than being designed to have the machines reproduce a more conventional written product for human perception. ${ }^{237}$

231. That supposition was inferable from the text of the law and was explicit in parts of the legislative history. See H.R. REP. NO. 94-1476, at 54 (1976) (cited by Apple Computer, Inc. v. Franklin Computer Corp., 714 F.2d 1240, 1247 (3d Cir. 1983)).

232. H.R. REP. NO. 94-1476, at 54.; cf. GORMAN ET AL., supra note 228 (explaining that Congress amended the Copyright Act on the basis of CONTU recommendations).

233. See NAT'L COMM'N ON NEW TeChNOLOGICAL UsES OF COPYRIGHTED WORKS, FINAL REPORT OF THE NATIONAL COMMISSION ON NEW TECHNOLOGICAL USES OF COPYRIGHTED WORKS (1978) [hereinafter FINAL REPORT], available at http://digital-law-online.info/CONTU/.

234. An Act of Dec. 12, 1980, Pub. L. No. 96-517, 94 Stat. 3015, 3028 (codified at 35 U.S.C. $\S \S 301-07$ ).

235. See FinAl RePORT, supra note 233; Apple Computer, 714 F.2d at 1249; see also infra text accompanying note 237.

236. Apple Computer, Inc. v. Franklin Computer Corp., 545 F. Supp. 812, 825 (E.D. Pa. 1982).

237. Apple Computer, 714 F.2d at 1249. 


\section{B. Fitting Software in the Intellectual Property System}

The conclusion that copyright provided a more natural home for protection of software was eminently sensible. ${ }^{238}$ Copyright principally safeguards against copying, not against unintended use of the same or similar concepts, creating less interference with valuable commercial activity. ${ }^{239}$ It intentionally has a lower bar to coverage combined with less robust protection than patent. 240

Copyright protection is especially appropriate to innovations that are reduced to writing-software programs inevitably are inscribed in some form-and involve substantial overlap from one set of innovations to another, much in the way that legal writings (though original) generally take prior works as their jumping off points. ${ }^{241}$ The incremental innovations in software in the main tend to be modest, with differences more in the way elements are ordered and combined than in a truly novel idea about accomplishing fundamental, practical tasks. ${ }^{242}$ As one scholar phrases the point, "the true novelty [of software] typically lies in how the software code is written, not the functional concepts of gathering, manipulating or displaying data that the code implements." 243 Smaller contributions to the stock of novel ideas, and especially contributions that are more in the nature of new ways of writing instructions, call for less impressive protections from the law. ${ }^{244}$ Copyright protects software against copying, preventing reverse engineering that could strip investment in software development of its value, but does not reach further to frustrate independent development of code that performs comparable functions. ${ }^{245}$

There is, to be sure, a difference between software code and the sort of literary work at the heart of copyright protection.

238. E.g., FINAL REPORT, supra note 233, at 11.

239. Id. at $8,11-12$.

240. E.g., CASS \& HYLTON, supra note 31, at 98-108.

241. E.g., FINAL REPORT, supra note 233, at 9-10.

242. E.g., CASS \& HYLTON, supra note 31, at 150; Bernard Chao, Finding the Point of Novelty in Software Patents, 28 BERKLEY TECH. L.J. 1217 (2013); Goldman, supra note 215, at 2; see also Richard R. Nelson, Intellectual Property Protection for Cumulative Systems Technology, 94 Colum. L. REV. 2674 (1994) (explaining that new technology such as software builds on technology already in existence).

243. Goldman, supra note 215, at 4 .

244. Id. at $4-5$.

245. E.g., CASS \& HYLTON, supra note 31, at 150. 
Software code is written to be directly connected to the functioning of machines, the hardware that software controls. ${ }^{246}$ Core literary works speak instead to the human condition, to our imaginations, our hopes and fears, our manifold interests, our aspirations, and our curiosities.

Copyright's periphery, however, is broad, and the law selfconsciously has declined to deny copyright coverage to works of authorship that are less highbrow or less fanciful. ${ }^{247}$ The particular expression contained in instruction manuals is copyrightable, though phrases in such manuals that are commonly used or difficult to replace without immense circumlocution are not protected. ${ }^{248}$ Even though software code is distinguishable in the directness of its connection to the world of practical functions, it is not so different as to fall outside the bounds of copyright. ${ }^{249}$

Similarly, copyright's length at first blush appears a strained fit with protection for software. Copyright lasts for seventy years beyond the life of the author or for roughly a century (the range is 95-120 years) from the date of publication for works made for hire. ${ }^{250}$ Software, in contrast, has a very short time frame; its value diminishes rapidly. ${ }^{251}$

Contrary to the inference that this makes copyright an inappropriate fit with software, the rapid depreciation of software's value supports the use of copyright. ${ }^{252}$ While it takes years to obtain patent protection, and longer to assure that the protection is secure, copyright attaches immediately, a special advantage with intellectual property products that have short time-value. ${ }^{253}$ Further, any deleterious effects of the long tail

246. E.g., Kevin Emerson Collins, Patent Law's Functionality Malfunction and the Problem of Overbroad, Functional Software Patents, 90 WASH. U. L. REV. 1399, 1442 (2013); Goldman, supra note 215, at 3.

247. See Apple Computer, Inc. v. Franklin Computer Corp., 714 F.2d 1240, (3d Cir. 1983); see also supra notes 235-37 and accompanying text.

248. E.g., H.R. REP. NO. 94-1476, at 53-56 (1976).

249. See id. ("Rather, the list sets out the general area of copyrightable subject matter, but with sufficient flexibility to free the courts from rigid or outmoded concepts of the scope of particular categories.").

250. See 17 U.S.C. $§ 302$ (2012).

251. See Goldman, supra note 215, at 2.

252. E.g., FinAL REPORT, supra note 233, at 1.

253. Cf. Goldman, supra note 215 , at 2 (providing that software lifecycles typically end before patents issue). 
on copyright (a much debated topic) ${ }^{254}$ likely will be irrelevant to software, as there is little prospect that it will be copied well into the future. At bottom, copyright law provides a fairly good fit with protection of software's intellectual contributions, balancing the benefits of supporting investment in innovation against the costs in interference with other valuable activity. ${ }^{255}$

Trade secret law also has a role to play in protecting software, though the fit here, too, initially looks poor. Trade secret law generally is best at protecting truly novel creations that are difficult to reverse-engineer and that have long-term value, substantially beyond the life of patent's protections. 256 The protection can be costly because it requires cabining information from people who might efficiently use it and because it generally is tied to employment contracts and the threat of litigation (which is an inducement to warm and fuzzy feelings in employment the same way that discussion of prenuptial contracts contributes to romantic conversations). ${ }^{257}$ In settings where a team works on an advance, such as in development efforts for complex software, the hopes for longterm secrecy are slight. ${ }^{258}$ Yet the very time limitation of software value that looks at odds with trade secret helps here; contractual arrangements can provide reasonably secure protection of some aspects of the software and at a minimum can assist in delaying diffusion of critical information to competitors. ${ }^{259}$ This does not, however, provide security against copying that can be done without assistance of the development

254. E.g., CASS \& Hylton, supra note 31, at 121-25; William M. LANDES \& Richard A. POSNer, THE ECONOMIC STRUCTURE OF InTElleCtuAL Property LAW ch. 2-3 (2003); Lawrence B. Solum, Congress's Power to Promote the Progress of Science: Eldred v. Ashcroft, 36 LOY. L.A. L. REV. 1, 6678 (2002); Avishalom Tor \& Dotan Oliar, Incentives to Create Under a "Lifetime-Plus-Years" Copyright Duration: Lessons from a Behavioral Economic Analysis for Eldred v. Ashcroft, 36 LOY. L.A. L. REV. 437, 437-44 (2002).

255. See, e.g., Tor \& Oliar, supra note 254, at 437-38.

256. E.g., CASS \& HYLTON, supra note 31, at 76-96; see also LANDES \& PosNeR, supra note 254, at 354-71. See generally David D. Friedman et al., Some Economics of Trade Secret Law, 5 J. ECON. PERSP. 61 (1991).

257. See, e.g., Friedman et al., supra note 256, at 67.

258. See FINAL REPORT, supra note 233, at 15-18 (comparing copyright protection to other methods, emphasizing the problems trade secrecy would pose to software).

259. Id. 
team, a point that was made in the early evaluation of copyright coverage as an additional protection. ${ }^{260}$

\section{Software And Patent: UnPaCking the Problems}

Protection of software under patent law has proved more controversial than protection under other intellectual property rights regimes. ${ }^{261}$ Courts set aside early reservations focused on whether granting software patents essentially requires locking up all innovation related to a mathematical formula or numerical algorithm, or instead can leave enough scope for invention to hold that other innovative components of software could be patented, but concerns over software patenting have remained. ${ }^{262}$ Key concerns include whether software patents are inevitably overbroad, whether patents are necessary to protect innovation in this arena, and whether the overlap with other intellectual property rights regimes that promote investment and shield its products from copying makes patent protection dangerous or unwise. ${ }^{263}$

\section{OVERBREADTH AND PATENT QUALITY}

Several commentators have observed that patents for software tend to be excessively broad, protecting functions that are not exclusively generated through the operation of the algorithm that is the special contribution of a particular software program. ${ }^{264}$ This complaint at times is joined with the observation that the U.S. Patent and Trademark Office (PTO) for many years gave relatively light scrutiny to software patents, essentially serving as an open door to software patenting. ${ }^{265}$ Precise definition of software patents is difficult and estimates of the number of software patent applications filed and patents granted varies dramatically, 266 but it is clear

260. E.g., id.

261. See supra Part IV.A.

262. See supra notes 218-27 and accompanying text.

263. E.g., Chao, supra note 242, at 1235-36; Collins, supra note 246, at 1403; Lemley, supra note 216; Goldman, supra note 215.

264. E.g., Collins, supra note 246, at 1464; Goldman, supra note 215, at 4.

265. E.g., Goldman, supra note 215 , at 8.

266. See, e.g., Robert Hunt \& James Bessen, The Software Patent Experiment, BUS. REV., Q3 2004, at 22, available at http://www.phil.frb.org /research-and-data/publications/business-review/2004/q3/brq304rh.pdf (estimating more than 20,000 software patents granted annually as of the early 2000s, based on a keyword search of invention descriptions in the PTO 
that the number of applications and grants in this field rose very substantially in the 1990 s to mid-2000s. ${ }^{267}$

There is little reason to believe that examiners at the PTO are inherently less knowledgeable about software than other technologies, less capable of inquiring into the novelty of software patent claims, or less able to examine the patentability of claimed elements as subjects within the scope of patent law. Software patent overbreadth may not be a permanent problem if, as seems plausible, the relatively easy grants of broad patents during the 1990s (and perhaps early 2000s) reflected examiners' uncertainty over the directions the courts were giving respecting software patents, or if the problem during the years in question flowed from a relative paucity of sound information on prior art in a fairly new and rapidly evolving field. 268

Some commentators have argued to the contrary, that the nature of software makes it inherently prone to overbroad patents. Professor Kevin Collins, for example, points out that software patents rely on mathematical formulae designed to govern specific functionality but are not tied to a particular machine or to the transformation of a given material, making these patents, in his view, purely functional. ${ }^{269}$ However, this may not point to a problem inherent in software patenting as a category.

While not expressly adopting a test that would limit patents to those that passed the machine-or-transformation test, the Supreme Court recently emphasized the importance of assuring that the elements of a patent claim that connect to the specific machine or transformation of a given material have sufficient novelty to support a patent grant.270 In its 2014

patent database); Jim Singer, Software Patent Statistics, IP SPOTLIGHT BLOG (Dec. 24, 2009), http://ipspotlight.com/2009/12/24/software-patent-statistics/ (providing that there was a high of 752 software patent grants by the PTO in 2006, declining to just over 700 the following two years); see also Chao, supra note 242 , at 1225 \& n.54, 1229-30 (comparing different definitions of software, resulting in different estimates of the number of patents).

267. See supra note 266.

268. See, e.g., Goldman, supra note 215, at 4 (suggesting the paucity of prior art as a possible cause of sparing examination and lenient grants of software patents).

269. E.g., Collins, supra note 246, at 1449.

270. E.g., Mayo Collaborative Servs. v. Prometheus Labs., Inc., 132 S. Ct. 1289, 1300 (2012); Bilski v. Kappos, 561 U.S. 593 (2010). 
decision in Alice Corp. Pty. Ltd. v. CLS Bank Int'l., the Supreme Court again stressed the need for software patents, like all patents, to be based on something beyond an abstract idea. ${ }^{271}$ The Court said that claim references to implementation of such an idea through computer functions must be specific enough and inventive enough to state a patentable inventiona step that was missing in Alice Corp.'s references to generic computerized implementation of the idea of intermediated settlement-but the Court did not find that software was inherently unpatentable or required special rules. ${ }^{272}$

The Supreme Court's continued emphasis on novelty and specification of the inventive elements suggests the availability of tools sufficient to permit the PTO to constrain software patents, just as it should constrain business method patents, biomedical patents, or any other patents.273 The PTO's Director has recognized the agency's past struggles to meter the scope, novelty, and nonobviousness of software patents appropriately and has instituted new initiatives to address these issues. ${ }^{274}$

The conclusion that software patents need not be overbroad-that PTO examiners have the leeway, and in fact have the obligation, under the existing legal rules to limit software patents as well as other patents-is not a denial of assertions that software patents frequently are overbroad, overstating the scope of the novel contribution made by the claimed innovation. ${ }^{275}$ Apart from the absolute level of problems with this category of patents, there is plenty of thoughtful commentary contending that this category of patents is relatively problematic compared to other patent categories-that these patents more often overstate the novelty of the innovation, more often include claims that extend too

271. Alice Corp. Pty. Ltd. v. CLS Bank Int'l., 134 S. Ct. 2347, 2347 (2014).

272. Id. at 2357.

273. Cf. Robert P. Merges, Software and Patent Scope: A Report from the Middle Innings, 85 TEX. L. REV. 1627, 1655-56 (2007) (urging, more generally, the availability of legal doctrines respecting patent grants as sufficient to limit software patents).

274. See David Kappos, Dir., U.S. Patent \& Trademark Office, Keynote Address at the Center for American Progress: An Examination of Software Patents (Nov. 20, 2012), available at http://www.uspto.gov/news /speeches/2012/kappos_CAP.jsp.; Software Partnership, U.S. PAT. \& TRADEMARK OFF., http://www.uspto.gov/patents/init_events/software _partnership.jsp (last updated Aug. 7, 2014).

275. E.g., Kappos, supra note 274. 
broadly, more often leave potential users of similar technology unclear about the scope of the legitimate legal protection, and more often are the subject of unsuccessful litigation than other categories of patents. 276

Despite contrary arguments about the quality of these patents as a whole, ${ }^{277}$ at a minimum the evidence supports the conclusion that many software patents present excessively broad or insufficiently well-defined claims. ${ }^{278}$ These are not the same objections: lack of definition (what has been referred to by Professors Bessen and Meurer as the "patent notice" problem) ${ }^{279}$ is a separate matter from patent quality-grants that exceed the scope of what is novel and nonobvious. 280 The quality problem is that award of patents more frequently in this field to inventions that do not meet statutory requirements incurs the social costs of patent protection without providing the offsetting social benefits of promoting novel invention. ${ }^{281}$ Of course, some errors (including some undeserved patent grants) are inevitable, but a large and asymmetric error rate threatens to up-end the social benefit that supports patents. ${ }^{282}$ There is no persuasive reason to expect that software patents will be systematically less clear than other patents; ${ }^{283}$ but, as the

276. E.g., BESSEN \& MEURER, supra note 11, at 201-03; Chao, supra note 242, at 1235-36; Collins, supra note 246, at 1140; Lemley, supra note 216, at 905; Goldman, supra note 215, at 8. But see Allison \& Mann, supra note 22.

277. E.g., Allison \& Mann, supra note 22, at 318.

278. Id.

279. But see BESSEN \& MEURER, supra note 11, at ch. 7 (arguing that software patents are more uncertain as a class due to the nature of the subject matter being patented). This is not a logical inevitability, as abstractness does not necessarily produce a lack of clarity and descriptions of specific tangible items are not unerringly clear; but that observation does not deny that early software patents frequently may have been less well-crafted and less clear than typical utility patents.

280. See, e.g., Goldman, supra note 215, at 4.

281. Id.

282. E.g., CASS \& HYLTON, supra note 31.

283. Moreover, the concerns about uncertainty in software patents stressed by Bessen and Meurer even if more robustly substantiated, are not obvious as reasons for problems in patent litigation. See BESSEN \& MEURER, supra note 11, at ch. 7. Uncertainty (along with the differential predictions about outcomes predicated on the information about which there is uncertainty) plays a complex role in decisions respecting suit and settlement generally. See, e.g., Lucian Arye Bebchuk, Litigation and Settlement Under Imperfect Information, 15 RAND J. ECON. 404, 405 (1984); Keith N. Hylton, Asymmetric Information and the Selection of Disputes for Litigation, 22 J. LEGAL STUD, 
following discussion indicates, the quality problem may be a special one with respect to software patents given other protections for software. In other words, even if the problem of patent quality in software patent grants turns out to be a transitory rather than an endemic condition (a matter that, as with the patent notice question, is open to contradictory predictions), ${ }^{284}$ there is still a basis for special concern over lowquality patents in this field. ${ }^{285}$

\section{E. Necessity for PATENT PRotection.}

Another argument against software patents contends that patent protection is unnecessary because software development confers substantial first-mover advantages ${ }^{286}$ or because innovation is sufficiently promoted by protections for software programs under copyright and trade secret law.287 Neither prong of this argument provides a basis for denying protection to software categorically. Nothing in the patent law or other intellectual property laws predicates eligibility for legal protection on the absence of other commercial advantage to innovation. ${ }^{288}$ Sectors such as software can generate significant network effects that tip consumers toward an initially successful technology and expand the benefits of innovation. ${ }^{289}$ But the same can be said of other sectors and other types of innovation-the classic example of these effects has been the QWERTY keyboard, which represents a practical-design choice for hardware. ${ }^{290}$

187, 196 (1993). There is no reason to expect different impact from uncertainty in patent litigation.

284. See, e.g., Kappos, supra note 274 (contending that some of the most troubling software patents on these scores have now expired and that mechanisms are in place to limit prospects for such grants going forward).

285. Id. 2 .

286. E.g., Chao, supra note 242, at 1224 n.46; Goldman, supra note 215, at

287. E.g., Chao, supra note 242, at 1224 n.46; Goldman, supra note 215, at 3.

288. See infra notes 291-92 and accompanying text.

289. E.g., Katz \& Shapiro, supra note 88, at 30; Lopatka \& Page, supra note 88 , at 343 .

290. E.g., W. Brian Arthur, Competing Technologies, Increasing Returns, and Lock-In by Historical Events, 99 ECON. J. 116, 126 (1989); Paul A. David, Clio and the Economics of QWERTY, 75 AM. ECON. REV. 332, 332-37 (1985); S. J. Liebowitz \& Stephen E. Margolis, The Fable of the Keys, 33 J.L. \& ECON. 1 (1990). 
Rejection of categorical exclusion of software from patent eligibility also accords with the text of current law, which does not exclude any set of patent applications that are able to meet the statutory tests for patent. ${ }^{291}$ It also accords with the treatment given by the Supreme Court in other cases where patent protection overlaps with another category of intellectual property protection, such as that provided under the plant protection acts. 292

\section{F. OVERLAP AND OVERPROTECTION}

However, when different legal regimes provide overlapping protections for a single innovation, there is a significant risk that cumulative protections will provide excessively broad rights to the innovator at the expense of those who would use or benefit from expanded exploitation of the innovation. ${ }^{293}$ This risk has been a concern at the boundaries between copyright and patent and between copyright and trademark for creative products such as ornamental designs and literary characters. ${ }^{294}$ While the exact scope and length of protection that is socially ideal is unknowable, adding the protections of one intellectual property system to those of another can up-end the generally sensible balance that is struck by each property rights regime. ${ }^{295}$

The risk of overprotection can be reduced where different intellectual property regimes protect different uses of a creative work (for example, derivative literary works using expressive features of a character from a copyrighted work and toys based on the trademarked character).296 In the case of software, however, both copyright and patent protect the same uses of the innovation, adding restrictions on the use of processes and methods of operation claimed in the patent to copyright's restrictions on reproducing the program's code. 297

291. See, e.g., BESSEN \& MEURER, supra note 11, at 204.

292. E.g., J.E.M. Ag Supply, Inc. v. Pioneer Hi-Bred Int'l, Inc., 534 U.S. 124, 145-46 (2001); Diamond v. Chakrabarty, 447 U.S. 303 (1980).

293. E.g., CASS \& HYLTON, supra note 31 , at 148-51.

294. E.g., id.

295. See, e.g., Nelson, supra note 242, at 2674.

296. See FINAL REPORT, supra note 233, at 16-18 (describing various IP regimes and their distinct protection purposes).

297. See, e.g., Nelson, supra note 242, at 2675-76. 
Concerns about overprotection are compounded where patents are awarded on claims that are not carefully limited to reflect the patent law's core requirements of novelty, nonobviousness, and utility. ${ }^{298}$ Whatever one makes of arguments respecting overbreadth in software patents as a strict matter of fit with patent rules, there is extra reason for the PTO to scrutinize software patent claims given the overlap with copyright. This may already be occurring, and more than a few software patents have been denied on reexamination, but the need for scrutiny of software patents should be taken seriously at the initial patent issue stage. 299

Heightened scrutiny for these patents is especially important given the way that low-quality patents can be used strategically in litigation ${ }^{300}$. Standard remedies for patent infringement create hold-up opportunities for litigation filed after the fact (after a product is being produced) against the producing enterprises-especially where the product is highly complex, and most of all where substantial losses would attend removing the product from the market to reconfigure it to be non-infringing. ${ }^{301}$ As explained above, although the case against providing statutorily available remedies to PAEs has not been made, PAEs are most likely to exploit the opportunities for strategic gain. 302

Prospects for such use of patents to extract value that is not associated with the use of the patented product or process - as in the NTP-RIM litigation-puts a premium on judicial abilities to sort through patent claims promptly and accurately, assuring that remedies are available only where valid patents are infringed. Those abilities, unfortunately, are apt to be tested in cases involving software patent claims, where difficult questions respecting the work done by

298. See supra notes $274-81$ and accompanying text.

299. The calculus of the most efficient means for testing questionable patents (captured in the balance between "police patrols" and "fire alarms" seen in other contexts) needs adjustment to reflect the effects that attach to patent awards, even if otherwise post-award screening of validity would have lower cost. On the more general question of ex ante versus ex post screening, see, for example, Mathew D. McCubbins \& Thomas Schwartz, Congressional Oversight Overlooked: Police Patrols Versus Fire Alarms, 28 AM. J. PoL. SCI. 165 (1984).

300. See, e.g., BESSEN \& MEURER, supra note 11, at 18-19.

301. See, e.g., id.

302. See supra Part III. 
mathematical formulae, the degree of limitation to particular machines or specified physical operations, and the amount of novelty or nonobviousness are often presented. ${ }^{303}$ The intersection of questionable patents, overbroad claims, strategic use of litigation against producers of complex commercial products, and chances for judicial error in dealing with the technologies at issue raises special risks of overprotection. 304

Recognition of these risks should caution judges and administrators reviewing patents asserted (or likely to be asserted) in such settings, software patents in particular, to be especially certain that the patents fully and clearly meet the legal tests. Reducing the incidence of legal error on this score will not resolve all of the problems associated with the litigation of patents that cover uses of creative-inventive work also protected by copyright in settings like those seen in the smartphone patent fights, but it at least will lower the risks and costs of overprotection and help re-balance the costs and benefits of intellectual property protections in this arena.

\section{CONCLUSION}

The smartphone wars are not over, but they have gone on long enough to yield a few lessons. First, most of the broad, categorical "fixes" to problems associated with the smartphone patent wars-problems associated with hold-up risks to uses of patented technologies by makers of highly complex productssweep too broadly, throwing out good claims as well as bad and needed remedies as well as questionable ones. Second, despite the problematic nature of most categorical solutions (such as barring injunctive relief to NPEs), there are some factors likely to be associated with high costs and significant risks of discouraging beneficial innovative activity. Two factors in particular deserve special note.

303. See supra Part IV.

304. That is a primary basis for calls to eliminate software patents, as well as for restrictions on PAE remedies. See, e.g., Wu, supra note 18. There is some evidence that courts are denying software patent claims asserted in litigation at a higher rate than other patent claims, but that this has not prevented significantly higher rates of litigation for these patents. See, e.g., John R. Allison et al., Patent Quality and Settlement Among Repeat Patent Litigants, 99 GEO. L.J. 677, 709 (2011). 
The first of these is the role of PAEs in patent litigation. PAEs can serve valuable, socially beneficial functions, but they have greater prospect than other patent plaintiffs, including other NPEs, to use patent litigation strategically to extract monetary rewards significantly in excess of patent value. Differences in litigation costs (especially discovery costs) and in pragmatic constraints on use of litigation to extract excessively large returns make PAE suits more problematic given any level of error in deciding the underlying patent issues. In a world of positive error rates, the combination of litigation costs and risk can provide effective levers for hold-up, and PAE suits are especially apt to use the levers to that end.

The other factor of special concern is patent quality, which has been a special concern with respect to software patents. Problems with software patent quality, and the peculiar problem of double-protection for software under both patent and copyright, can exacerbate problems in the underlying patent litigation system, especially those evidenced in the mobile device area. This does not mean that there is no room for patents on truly novel, innovative software innovations, appropriately limited. But, as with other patents, awards of overbroad, non-novel, or obvious software patents generate costs, which have been particularly evident in the smartphone wars. The risk of a misapplication of the law in such instances-resulting in billion-dollar damage verdicts as in the Apple-Samsung case or in the prospect of excluding a firm's key products from the market or in effectively shutting down critical company operations, a result that had become imminent in the NTP-RIM litigation-is an inducement for firms that have sound positions on patent law to compromise, for firms that have questionable positions to press ahead, and for everyone to incur costs that clearer rules and more predictable application would reduce.

The answer to problems encountered in the smartphone wars does not need to reach as far as barring PAE suits, eliminating software patents, or making traditionally available remedies categorically off-limits for PAEs or for complaints of infringement of software patents. Instead, what is needed at a minimum-and can be implemented immediately without additional legislation-is heightened sensitivity to the risks associated with lax application of novelty and nonobviousness requirements in the context of software patents and sensitivity to the risks injunctive relief poses to PAEs asserting weak patents on minor innovations used in complex products. In the 
same vein, the PTO can invest in improved education for patent examiners respecting issues presented in software patenting, enhanced databases for prior art, and increased review of software patenting to monitor quality issues-all matters within the agency's purview if not necessarily within its budget. Finally, and most difficult to design appropriately, legislative attention to the issue might reduce costs from PAE litigation of low-quality software patents in contexts, such as the smartphone litigation, where strategic behavior is most expected and most difficult to control.

Ultimately, focus on the smartphone wars should be less concerned with concluding that something has gone wrong than on what to do about it. Learning the right lessons from wars makes the inevitable next one less frightening. Learning the wrong lessons makes for expensive investment in the Maginot Line. 